\title{
INTEGRATED MINED-AREA RECLAMATION AND LAND-USE PLANNING
}

\author{
Volume $3 E$
}

A Case Study of Surface Mining and Reclamation Planning: ASARCO Open Pit Copper Mine, Casa Grande, Arizona

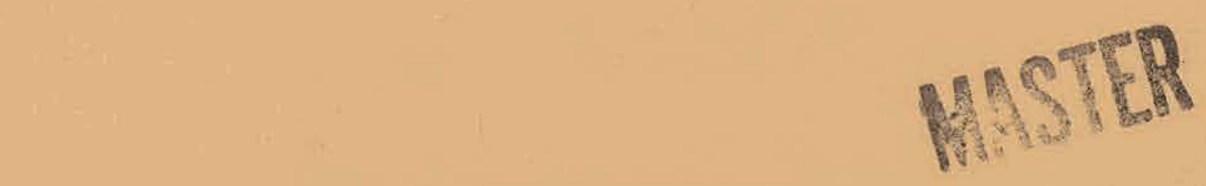

Prepared for the

Resource and Land Investigations (RALI) Program

U. S. Department of the Interior

U. S. Geological Survey

\section{ENERGY AND MINERAL RESOURCES}

ARGONNE NATIONAL LABORATORY

Energy and Environmental Systems Division

Operated for

U. S. ENERGY RESEARCH AND DEVELOPMENT ADMINISTRATION 


\section{DISCLAIMER}

This report was prepared as an account of work sponsored by an agency of the United States Government. Neither the United States Government nor any agency Thereof, nor any of their employees, makes any warranty, express or implied, or assumes any legal liability or responsibility for the accuracy, completeness, or usefulness of any information, apparatus, product, or process disclosed, or represents that its use would not infringe privately owned rights. Reference herein to any specific commercial product, process, or service by trade name, trademark, manufacturer, or otherwise does not necessarily constitute or imply its endorsement, recommendation, or favoring by the United States Government or any agency thereof. The views and opinions of authors expressed herein do not necessarily state or reflect those of the United States Government or any agency thereof. 


\section{DISCLAIMER}

Portions of this document may be illegible in electronic image products. Images are produced from the best available original document. 
The facilities of Argonne National Laboratory are owned by the United States Government. Under the terms of a contract (W-31-109-Eng-38) between the U. S. Energy Research and Development Administration, Argonne Universities Association and The University of Chicago, the University employs the staff and operates the Laboratory in accordance with policies and programs formulated, approved and reviewed by the Association.

\section{MEMBERS OF ARGONNE UNIVERSITIES ASSOCIATION}

The University of Arizona Carnegie-Mellon University Case Western Reserve University The University of Chicago University of Cincinnati Illinois Institute of Technology University of Illinois Indiana University Iowa State University The University of Iowa
Kansas State University The University of Kansas Loyola University Marquette University Michigan State University The University of Michigan University of Minnesota University of Missouri Northwestern University University of Notre Dame
The Ohio State University Ohio University The Pennsylvania State University Purdue University

Saint Louis University Southern Illinois University The University of Texas at Austin Washington University Wayne State University The University of Wisconsin

\section{NOTICE}

This report was prepared as an account of work sponsored by the United States Government. Neither the United States nor the United States Energy Research and Development Administration, nor any of their employees, nor any of their contractors, subcontractors, or their employees, makes any warranty, express or implied, or assumes any legal liability or responsibility for the accuracy, completeness or usefulness of any information, apparatus, product or process disclosed, or represents that its use would not infringe privately-owned rights. Mention of commercial products, their manufacturers, or their suppliers in this publication does not imply or connote approval or disapproval of the product by Argonne National Laboratory or the U. S. Energy Research and Development Administration. 
ARGONNE NATIONAL LABORATORY

9700 South Cass Avenue

Argonne, Illinois 60439

\author{
INTEGRATED MINED-AREA RECLAMATION \\ AND LAND-USE PLANNING \\ Volume $3 \mathrm{E}$ \\ A Case Study of Surface Mining and Reclamation Planning: \\ ASARCO Open. Pit Copper Mine, \\ Casa Grande, Arizona \\ by \\ John L. Thames, * Tika R. Verma,* \\ and James $R$. LaFevers \\ Energy and Environmental Systems Division
}

Prepared for the Resource and Land Investigations (RALI) Program of the U. S. Department of the Interior

with Funds Provided by the

U. S. Geological Survey

*Consultant to Argonne National Laboratory

This report was prepared as an account of work sponsored by the United States Government. Neither the

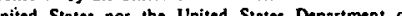
Conction Energ, nor ony

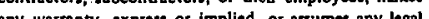
any warranty, express or implied, or arsumes any lega thab illy or responsibuly for the accuracy, completeness or usefulness of any information, apparatus, product or process disclosed, or represents that its use would not infringe privately owned rights. 
FOREWORD ............................ 1

ACKNOWLEDGMENTS . . . . . . . . . . . . . . . . . . . 3

PROGRAM STAFF . . . . . . . . . . . . . . . . . . 4

ABSTRACT . . . . . . . . . . . . . . . . . . 5

1 INTRODUCTION ...................... 5

2 REGIONAL PERSPECTIVE . . . . . . . . . . . . . . 7

2.1 Physiographic and Geologic Setting . . . . . . . . . . . 7

2.2 Climatic Conditions Affecting Reclamation .......... 8

2.3 Soils . . . . . . . . . . . . . . . . . . 8

2:4 Hydrological Conditions Affecting or Affected by the

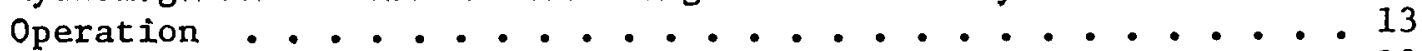

2.5 Land Use and Ownership Patterns . . . . . . . . . . . 13

3 MINING DATA . . . . . . . . . . . . . . . . . . 17

3.1 History of the Operation ................. . 17

3.2 Operating Company. ... . . . . . . . . . . . . . 18

3.3 Mineral Rights ...................... 23

3.4 Land Values and Taxation Policies . . . . . . . . . . . 23

3.5 Future Development Plans . . . . . . . . . . . . . 23

3.6 Commodity Description . . . . . . . . . . . . . . 25

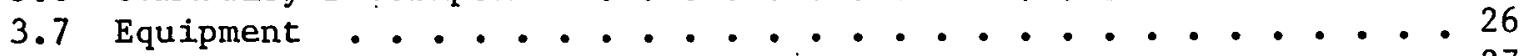

3.8 Production Costs . . . . . . . . . . . . . 27

3.9 Mining Methods ..................... 27

3.10 Importance of the Operation to the Local Economy . . . . . . 28

4 PROCESSING . . . . . . . . . . . . . . . . . 33

4.1 Location and Size of Facilities . . . . . . . . . . . 33

4.2 Type of Operation and Final Product ........... 34

4.3 Transportation and Storage Systems . . . . . . . . . . 35

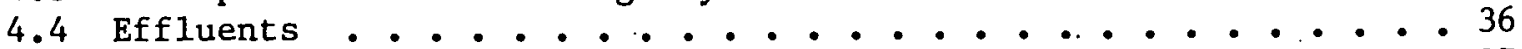

4.5 Chemicals Used in Processing . . . . . . . . . . . . 37

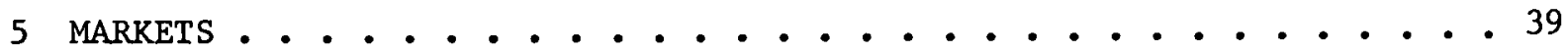

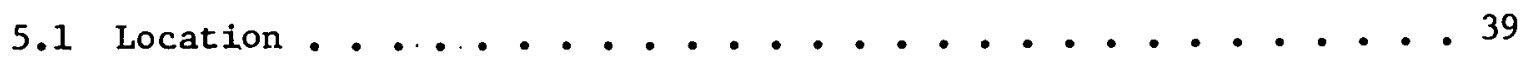

5.2 Market Reliability and Fluctuations . . . . . . . . . . 39

5.3 Competition . . . . . . . . . . . . . . . . 39

5.4 Prices . . . . . . . . . . . . . . . . . . . 40

6 DESCRIPTION OF DISTURBED AREA . . . . . . . . . . . . . 41

6.1 Spolls ........................ 41

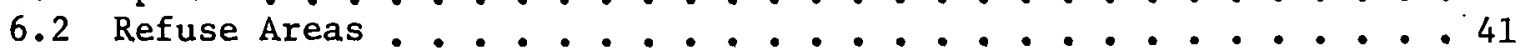


Page

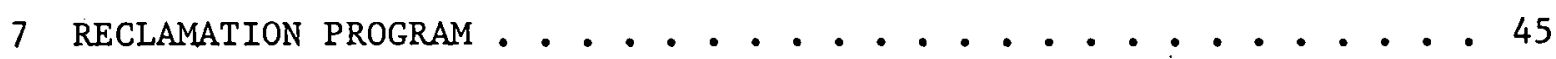

7.1 History of Reclamation . . . . . . . . . . . . 45

7.2 Current Reclamation Practices .............. 47

7.3 Availability of Supplies, Labor, and Equipnent . . . . . . 51

7.4 Costs ........................ 51

7.5 Benefits....................... 51

7.6 Reclamation Laws .................. 52

7.7 Reclamation Planning . . . . . . . . . . . . . . 52

7.8 Reclamation Research Program Onsite . . . . . . . . . 52

7.9 Data Inventory . . . . . . . . . . . . . . . . 54

7.10 Unique Problems . . . . . . . . . . . . . . . 54

8 OBSERVATIONS FOR PLANNERS . . . . . . . . . . . . . . 55

APPENDIX: Offices, Mining Properties, and Assoc1ates of ASARCO, Inc. . 57

BIBLIOGRAPHY . . . . . . . . . . . . . . . . 61

\section{LIST OF FIGURES}

2.1 Soil Associations of Pinal County . . . . . . . . . . . . 11

2.2 Soil Associations of the Sacaton Mine Site. . . . . . . . . . 14

2.3 Mining Land Use in Arizona . . . . . . . . . . . . . . 15

2.4 ASARCO Sacaton Mine Land Ownership . . . . . . . . . . . 16

3.1 Location of Copper Mines in Arizona . . . . . . . . . . . 20

3.2 Sacaton Mine Unit . . . . . . . . . . . . . . . . 22

3.3 Sacaton Mine Pit . . . . . . . . . . . . . . 22

4.1 Location of the Sacaton Copper Mine . . . . . . . . . . . . 33

4.2 Piping of Thickened Slurry . . . . . . . . . . . . 36

6.1 Reclamation at the Sacaton Copper Mine . . . . . . . . . 42

6.2 Flat-Top Spoil Benches . . . . . . . . . . . . . 43

7.1 Revegetated Water Tank Hill . . . . . . . . . . . . 46

7.2 Desert Shrub Environment at Sacaton Mine . . . . . . . . 48

7.3 Irrigation at Sacaton Mine . . . . . . . . . . . . . 49

7.4 Reclamation Site after Irrigation Withdrawal . . . . . . . 49

7.5 Nursery-Grown Native Trees and Shrubs . . . . . . . . . . 50

7.6 Use of Paper Erosion Control Fabric . . . . . . . . . . . 53 
2.1 Climatological Data, Sacaton Mine... . . . . . . . . . 9

3.1 History of Development . . . . . . . . . . . . . 18

3.2 Land Use by Sacaton Mine . . . . . . . . . . . . . . 23

3.3 History of ASARCO, Inc. . . . . . . . . . . . . . 24

3.4 Equipment Used in Stripping . . . . . . . . . . . . . 26

3.5 Equipment Used to Drill, Blast, and Haul Material . . . . . . . 26

3.6 Equipment Used for Road Maintenance and Dust Control . . . . . 27

3.7 County Government Revenues Provided by the Arizona Copper Industry, 1970-1973 . . . . . . . . . . . . . . 29

3.8 Arizona State Government Revenues Provided by the Copper Industry, 1970-1974 . . . . . . . . . . . . . 30

3.9 Total State and Local Government Revenues Provided by the Arizona Copper Industries . . . . . . . . . . . . 31 


\section{THIS PAGE \\ WAS INTENTIONALLY \\ LEFT BLANK}


FOREWORD

This report is one in a ten-volume series prepared by the Energy and Environmental Systems Division of Argonne National Laboratory and the Resource and Land Investigations (RALI) Program of the U.S. Department of the Interior under the sponsorship of the U.S. Geological Survey. Because of the close interrelationship of the ten documents in the series, each volume will be most useful only when its relationship to the other products of the program is considered.

The reports in this series are designed primarily to familiarize professional land use and resource planners with the range of possibilities and effective procedures for achieving integrated mining, reclamation, and land use planning. These reports are based on a research program which included an extensive literature review, the compilation and analysis of case study data, and close coordination and interaction with related government programs.

The first volume in the series, $A$ Guide to Integrated Mined Area Reclamation and Land Use Planning, summarizes the information in the other volumes and presents conclusions and observations drawn from analyses of that information. Volume 2, Methods and Criteria for Land Use and Resource Planning in Surface Mined Areas, examines planning procedures used in several mineral industries and mining regions and discusses problems facing professional planners who must consider surface mine areas in their planning programs.

In Volume 3, A Guide to Mined Area Reclomation Techrology for Reclcomation and Land lise Planners, the methods used to reclaim land in each of several mineral industries are discussed in relation to the physical and cultural constraints that must be considered in planning a reclamation program. Much of the information for this document was obtained from case studies conducted in several mining districts. The case study sites were chosen after consideration of the following: (a) coverage by commodity of those surface mining activities that disturb the greatest acreages, (b) coverage of a variety of cultural and land use settings, (c) evidence of integration of mining, reclamation, and land use planning, (d) cooperation on the part of operating companies and appropriate planning entities, (e) coverage of a variety of surface mining and reclamation methods, and (f) coverage of a variety of physical settings (geology, physiography, climate, hydrology). After the preliminary case study selection, some sites were changed and others dropped because of a lack of company cooperation. The remaining six case studies all meet the criteria listed above. They are not intended to be perfect examples of reclamation and planning procedures. Rather, they illustrate a variety of procedures utilized in different physical and cultural settings to achieve planning goals under a variety of technological, legal, and economic constraints.

Since the case studies are intended to be used as appendices to Volume 3 , they are numbered accordingly. The case study reports include:

Volume 3A: A Case Study of Surface Mining and Reclamation Planning: South Boulder Creek Park Project, Sand and Gravel operations, Boulder, Colorado. 
Volume 3B: A Case Study of Surface Mining and Reclomation Planning: International Minerals and Chemical Corporation, Phosphate Operations, Polk County, Florida.

Volume 3C: A Case Study of Surface Mining and Reclamation Planning: Georgie Kaolin Company, Clay Mines, Washington County, Georgia.

Volume 3D: A Case Study of Surface Mining and Reclamation Planning: Area Strip Coal Mining, Peabody Universal Mine, Universal, Indiana.

Volume 3E: A Case Study of Surface Mining and Reclomation Planning: ASARCO Open Pit Copper Mine, Casa Grande, Arizona.

Volume 3F: A Case Study of Surface Mining and Reclamation Planning: Cannelton Mountain-Top Removal Coal Mine No. 9-S, Cannelton, West Virginia.

Volume 4, A Bibliography of Integrated Mined Area Reclomation and Land Use Planning, With Annotations, includes primarily references pertinent to reclamation planning and plan implementation. 
We would like to thank those organizations and individuals whose cooperation, assistance, and advice have been helpful in the preparation of this report. Dr. Thomas J. O'Neil and Dr. Fred S. Matter of the University of Arizona were most helpful in providing background information. Thomas $R$. Edwards and Stuart A. Bengson of ASARCO, Inc., were especially helpful in providing much of the data for this report. We would also like to thank the following individuals for their review of and suggestions concerning this document:

Dr. Allen Agnew, The Library of Congress.

Frank Beal, Illinois Institute for Environmental Quality.

Dr. Roy E. Cameron, Argonne National Laboratory.

Denton Carlson, Bureau of Land Management.

Ralph P. Carter, Argonne National Laboratory.

Dr. Grant Davis, Surface Environment and Mining, U.S. Department of Agriculture.

Dr. Donald Everhàrt, International Minerals \& Chemical Corp.

James L. Gober, Tennessee Valley Authority.

Gene Harris, U.S. Environmental Protection Agency.

Edgar A. Imhoff, Resource and Land Investigations (RALI) Program, U.S. Dept. of the Interior.

Dr. Donald 0. Johnson, Argonne National Laboratory.

Kathryn S. Macal, Argonne National Laboratory

Charles Medvick, Illinois Dept. of Mines \& Minerals.

Dr. Meredith E. Ostrom, State Geologist of Wisconsin.

Olga Skala, Argonne National Laboratory.

Dr. John F. Tschanz, Argonne National Laboratory.

Dr. Charles E. Wier, Amax Coal Co. 
Dr. James R. LaFevers, Program Manager

Allen 0. Perry

Leslie R. Lewis

Jean E. Bogner

Ralph P. Carter

William R. Rice (Student Participant)

Robert Beck (Student Participant)

Energy and Environmental Systems Division, Argunne Nationa1 Laboratory

Edgar A. Imhoff, USGS-RALI/ANL Program Coordinator Dr. Joseph $\mathrm{O}^{\prime}$ Connor

Dr. Thomas Friz

Resources and Land Investigations Program, U.S. Department of the Interior

Dr. John L. Thames

Dr. Tika R. Verma

School of Renewable Natural Resources, University of Arizona

Dr. J. Lee Guernsey

Michae1 E. Tiller

Department of Geography,

Indiana State University

Dr. Lawrence A. Brown

Troy State University of Fort Rucker, Alabama

Richard Fountain

Fountain and Associates

Winter Haven, Florida

Dr. Erkan Esmer

Esmer and Associates

Boomer, West Virginia 
INTEGRATED MINED-AREA RECLAMATION AND LAND USE PLANNING

Volume 3E: A Case Study of Surface Mining and Reclumation Planning: ASARCO Open Pit Copper Mine, Casa Grande, Arizona

by

John L. Thames, Tika R. Verma, and James R. LaFevers

ABSTRACT

The premining geologic setting, mining activities, and reclamation experiments of the Sacaton open-pit mine and mill located near Casa Grande, the newest of ASARCO's copper mines in Arizona, are detailed in this case study. The mine's annual capacity of 21,000 tons boosts the annual domestic capacity of the company to more than 100,000 tons.

Mining data includes a history of the company and its operations, along with a description of its economic impact, production costs, and processing equipment. Reclamation is discussed in most of its aspects, such as history, current practices, laws, planning, and research. This case study illustrates some of the experimental practices being attempted to revegetate various parts of the mine site without returning the area to original contour, and despite not being legally required in Arizona.

\section{INTRODUCTION: SACATON COPPER MINE}

Arizona produces $54 \%$ of the copper output of the United States. This percentage represents more copper output than that from all other states as well as more than that of any country in the free world. The copper industry of Arizona employs over 24,000 people. The circulation and recirculation of copper industry wages, benefits, taxes, purchases, and other dollars have a combined impact on that state's economy of more than $\$ 3$ billion annually.

ASARCO Incorporated, which is one of the larger copper mining companies in the state, has located most of its copper mines in Arizona. The newest of these, the Sacaton open-pit mine and mill near Casa Grande, began production early in 1974. The mine's annual capacity is 21,000 tons, boosting the company's annual domestic mine capacity to more than 100,000 tons. The company expects to use underground techniques to mine a second, deeper ore body at Sacaton by 1980 .

The Sacaton unit is encountering production and reclamation problems similar to those of other copper mines in the southwest. This site was chosen as a case study, however, not only because of its newness, but also because it has a complete long-range reclamation plan. Having the plan lends 
added significance to the selection, since reclamation is not legally required. in Arfzona and hence all operations have not formulated such plans. ASARCO's reclamation plan was prepared prior to mining and includes a complete reclamation program for the site with the exception of the pit. Some of the reclamation work is done as mining progresses, but much of 1 t has to be done after mining is completed.

Reclamation of copper mine sites in the southwest is recognized as being primarily experimental. Because of the physical aspects of the mining operation, which are discussed in this report, returning the entire site to premining topography is not economically feasible under current economic and technological conditions. This case study illustrates some of the experimental practices that are being attempted to revegetate various parts of the mine site without returning the entire area to original contour. Reclamation planning and the potential for reuse of the site after mining are limited by the sparseness of. the population of the region. Low land use demands tend to depress property values and also limit the varlety of end uses that would be feasible in a reclamation plan. All of the planning going into the reclamation program at the Sacaton Mine is being done in-house by the ASARCo staff. Projections of local land use needs were taken into consideration, however, in the development of the existing reclamation plan, which is intentionally left flexible enough for the incorporation of future developments. 


\section{REGIONAL PERSPECTIVE}

\subsection{PHYSIOGRAPHIC AND GEOLOGIC SETTING}

The Sacaton copper mine is located about six miles northwest of Casa Grande in a valley adjacent to the southwest flank of the Mountains in southern Arizona. The area lies within the Sonoran Desert section of the Basin and Range province. The land surface consists of broad, nearly level valley plains and sloping fans that turn to these mountains on the north. Elevation ranges from $1350 \mathrm{ft}$ on the flood plain near the North Branch of the Santa Cruz Wash, which drains the area, to about $2800 \mathrm{ft}$ in the mountains. The wash is neither perennial nor deeply entrenched, and flooding frequently results from torrential summer rains. General physiographic features include mountains, pediments, and plains on which several isolated buttes are located. The pediments, or eroded rock surfaces, slope gently outward and disappear beneath alluvium on the plains.

The geologic structure and origin of the Basin and Range province are characterized by many linear mountain ranges rising abruptly from the valley floor. Precambrian metamorphic and igneous crystalline rocks form the core of the most prominent mountain ranges. Successive generations of mountain buildup have created deep structural troughs that gradually have collected sedimentary material from a wide variety of parent rocks due to alluvial and wind action. The Precambrian and Tertiary rocks that occur in, or underneath, the area are granite, schists, gneiss, quartzite, andesite, and dacite with Quaternary basalt present in places.

The formations outcropping near the Sacaton mine site include the older Precambrtan Pinal schist and Oracle grantte and the younger Precambrian Sacaton granite. The base rock materlal is partially covered by Tertiary conglomerates and Quaternary alluvium.

Predominant pre-mineral rock types at the mine are Precambrian granite and a monzonite porphyry intrusion of Laramide age. Drill-hole information reveals that two copper deposits, an east and a west, are present in the mine area, and that monzonite porphyry is centered near the southwest side of the west deposit. Subsequent geologic mapping in the open pit further indicates that a complex intrusive relationship exists between the granite and monzonite porphyry.

Post-mineral andesite porphyry dikes intrude among the overlying rocks and post-mineral conglomerate and alluvium completely cover both of the copper deposits and most of the altered zone. The alluvium cover ranges in thickness from 60-100 ft; and the conglomerate increases to $600 \mathrm{ft}$ over the western deposit and from 700-1500 ft over the eastern one.

On a regional scale, the Sacaton deposits are located on a major northeasterly trending zone containing Laramide stocks and several producing copper mines. This zone is evidenced by a northeast elongation of the alteration zone containing the Sacaton deposits. To the northeast, the zone passes through or adjacent to copper deposits at Superior and Miami. In short, the structure of the deposit is complex with intensely fractured and faulted rocks among fractures of varfous orfentations. 
Temperature and precipitation are significant factors in reclamation. The climate of the Sacaton site is hot and dry. Prectpitation is extremely variable but averaged only 4.26 inches in $1973,7.34$ in 1974 , and 6.21 in 1975 (Table 2.1). Not only is the rainfall low in amount and irregular from year to year, but the distribution of prectpitation throughout the year is also extremely erratic. The average annual potentlal evapotranspiration is about 45 inches; consequently, high molsture deficlencies are common to the area.

The temperatures for the complete three-year sampling period ranged from a low of 20 to a high of $116^{\circ} \mathrm{F}$. For approximately 150 days per year, the temperatures were $90^{\circ} \mathrm{F}$ or more, and during periods of 10 days per year dropped below freezing. The site is also exposed to periodic dry winds and intense solar heating. The relatively cloud-free skies, high diurnal ranges in temperature, and infrequent preclpitation all make reclamation more difficult.

In short, the Sacaton mine area has a growing season of sufficient length to permit the growth of a wide variety of crops, although the season varies from 250 to 300 days per year. However, the site is devoid of molsture and subject to great fluctuations of temperature. Since the potential evapotranspiration rate is several times the annual precipitation, a persistent lack of adequate soil moisture is an ever-present problem affecting reclamation.

\subsection{SOILS}

In addition to the very low and erratic precipitation, another obstacle to successfully establishing vegetation is the soil problem. Topsoll is either scarce or non-existent in most of the Sacaton mine site. The soils occur on gently sloping fans and broad, nearly level valley plains adjacent to the Santa Cruz Wash. Deep, medium- to fine-textured soils are on the valley plains; whereas, deep, moderately coarse, and gravelly soils are on the alluvial fans. Saline-alkali, high lime, and lime-silica pan soils are scattered and occur locally. The parent materlals of the soils consist of a mixture of igneous, sedimentary, and metamorphic rocks, and poor drainage conditions are prevalent in the valley plain.

The Sacaton copper mine is surrounded by the Typic Torrifluvents (Antho-Valencia Series) in the northwest, Typic Paleorthids (Collidge-Cavelt Series) in the north at the foot of the Sacaton Mountains, and Typic Natragids (Casa Grande Series) in the east and the south. Figure 2.1 shows the typical soil associations in Pinal County.

The soils on the mining site are also Typic Natragids (Casa Grande Series). These soils are of loam to sandy loam in texture, formed in old, mixed alluvium. The analysis of the samples taken from the soils on the mine site indicated low plant nutrients ( $34 \mathrm{ppm} \mathrm{NO}, 1-3 \mathrm{ppm} \mathrm{PO}_{4}$ ), $\mathrm{pH}$ 7.9-8.7, 700-1800 ppm TSS, 5-18 ESP, 33-39 ppm Ca. The soil texture is coarse loam ( $66 \%$ sand, $17 \%$ silt and $17 \%$ clay). Yet the biggest problem may not be the 
Table 2.1. Climatological Data (Sacaton Mine)

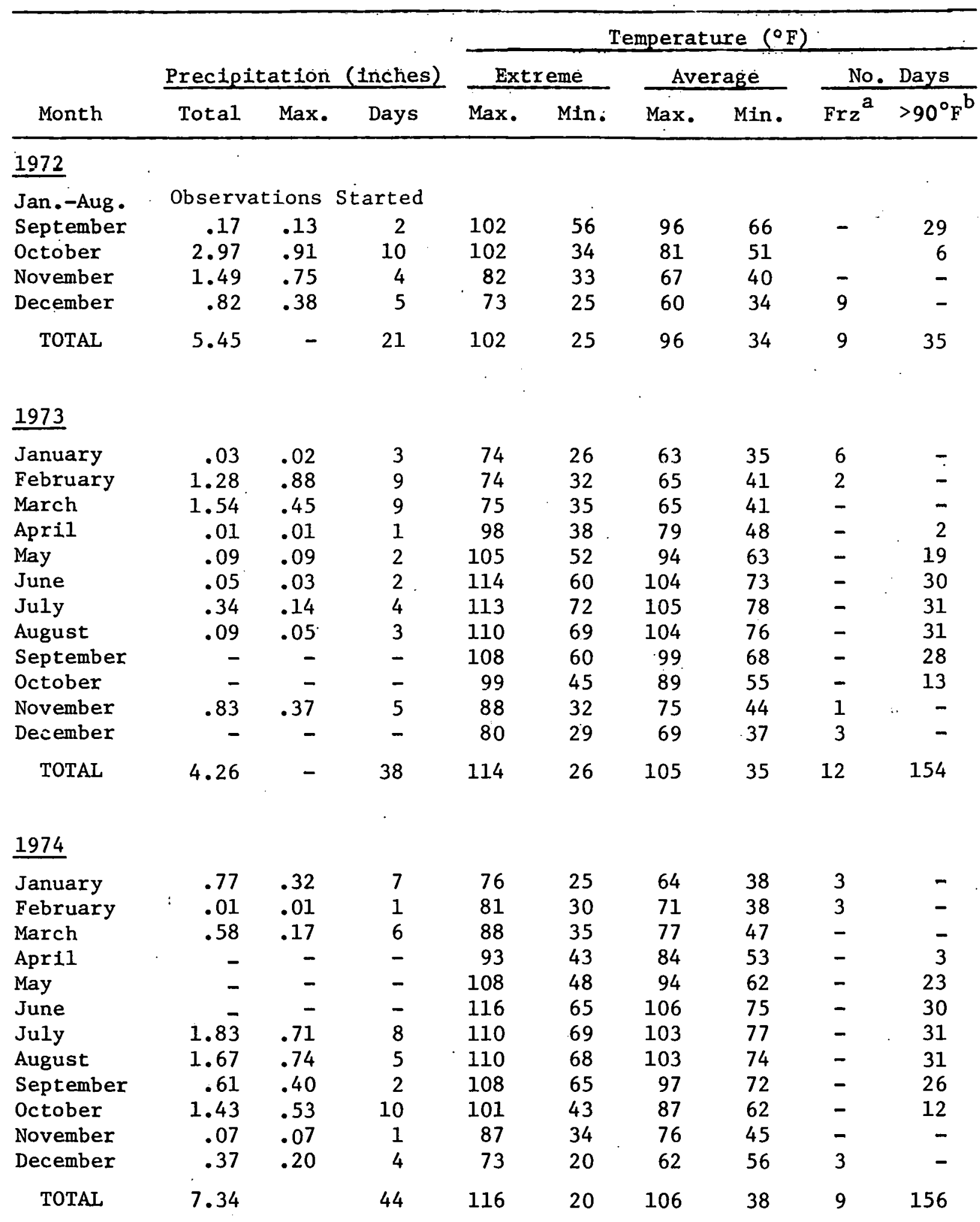


Table 2.1. (Cont'd)

\begin{tabular}{|c|c|c|c|c|c|c|c|c|c|}
\hline \multirow[b]{3}{*}{ Month } & \multirow{2}{*}{\multicolumn{3}{|c|}{ Precipitation (inches) }} & \multicolumn{6}{|c|}{ Temperature $\left({ }^{\circ} \mathrm{F}\right)$} \\
\hline & & & & \multicolumn{2}{|c|}{ Extreme } & \multicolumn{2}{|c|}{ Average } & \multicolumn{2}{|c|}{ No. Days } \\
\hline & Total & Max. & Days & Max. & Min. & Max. & Min. & $\operatorname{Frz}^{\mathrm{a}}$ & $>90^{\circ} \mathrm{F}$ \\
\hline \multicolumn{10}{|l|}{1975} \\
\hline January & .04 & .02 & 2 & 82 & 22 & 66 & 38 & 8 & - \\
\hline February & .78 & .56 & 5 & 81 & 27 & 67 & 39 & 3 & - \\
\hline March & 1.18 & .95 & 7 & 85 & 32 & 73 & 45 & 1 & - \\
\hline April & .61 & .28 & 5 & 89 & 40 & 78 & 48 & - & - \\
\hline May & - & - & - & 105 & 46 & 91 & 59 & - & 17 \\
\hline June & - & - & - & 109 & 63 & 102 & 70 & - & 27 \\
\hline July & .85 & .70 & 5 & 110 & 74 & 105 & 79 & - & 31 \\
\hline August & .15 & .12 & 3 & 113 & 71 & 105 & 77 & - & 31 \\
\hline September & .33 & .28 & 3 & 107 & 63 & 100 & 72 & - & 30 \\
\hline October & .71 & .70 & 2 & 100 & 40 & 89 & 57 & - & 16 \\
\hline November & .95 & .68 & 2 & 93 & 33 & 76 & 47 & - & 2 \\
\hline December & .61 & .51 & 2 & 80 & 31 & 67 & 41 & 3 & - \\
\hline TOTAL & 6.21 & - & 36 & 113 & 22 & 105 & 38 & 15 & 154 \\
\hline \multicolumn{10}{|l|}{1976} \\
\hline January & .01 & .01 & 1 & 86 & 25 & 68 & 39 & 7 & - \\
\hline February & .66 & .35 & 4 & 83 & 40 & 74 & 47 & - & - \\
\hline March & .39 & .31 & 2 & 89 & 33 & 75 & 46 & - & - \\
\hline April & .48 & .25 & 3 & 94 & 38 & 82 & 53 & - & 3 \\
\hline May & .42 & .26 & 3 & 103 & 54 & 94 & 64 & - & 25 \\
\hline June & Trace & - & 1 & 113 & 64 & 103 & 73 & - & 29 \\
\hline Ju1y & 1.30 & .55 & 9 & 113 & 73 & 103 & 78 & - & 31 \\
\hline August & 1.02 & .39 & 4 & 109 & 72 & 103 & 76 & - & 31 \\
\hline September & 1.95 & .90 & 7 & 103 & 60 & 94 & 70 & - & 26 \\
\hline October & .06 & .03 & 3 & 94 & 45 & 83 & 57 & - & 6 \\
\hline November & - & - & - & - & - & - & - & - & - \\
\hline December & - & - & - & - & - & - & - & - & - \\
\hline TOTAL & & & & & & & & & \\
\hline
\end{tabular}

a Number of days at or below freezing.

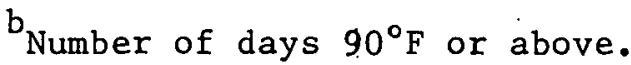






Fig. 2.1. Soil Associations of Pinal County (Legend follows) 
LEGEND

GENERAL SOIL

PINUL COUNTY, ARIZON

SOILS OP THE FLOOD PLAINS

A1 Cllman-Antho-Pimer as sociation

Deep, medium, moderately coarse, and moderately fine-textured - lluvial soilo, 0 to 3 percent olopes.

A2 Torrifluvento association

Mixed alluvial land oubject to frequent overflow, 0 to 3 percent -lopes.

SOTLS OF THE VALLEY SLOPES

B! Mohall-Casa Grande associaction

Deep, moderately fine and medium-textured reddioh solle,

0 to 2 percent slopes.

B2 Mohall-pinamt association

Deep, moderately fine, and very gravelly moderately fine-textured raddith oolls of the higher fans, 0 to 5 percent olopes.

B3 Casu Grande-LaPalme assoclation

Doep and moderately deep, medium and moderately fine-textured, saline-alkall, reddioh solls, 0 to 2 percent slopis.

B4 Mohall-Vecont association

Deep, moderately fine and fine-textured reddish soils, 0 to 2 percent olopea.

B5. White Ho sse-Caralampl assoclation

Deep, fine, and gravelly moderacely fine-textured reddish soils with dark colored surtaces, 2 to 8 percent olnpes.

86. Caralampi-whice Huse asooclation

Deep, giavelly moderately fine and $f$ ine-textured reddiah soils with dark colored surfaces, 5 to 30 percent slopes.

B7 Caralampi assockation

Deep, gravelly moderately fine-textured reddish solls with dark colored surfaces, 30 to 60 percent alopes.

SHALLOW SOILS OVER BEDROCK

CI Chiricahua assoclation

Shallow, gravelly or cohbly moderately fine-textured solls over bedrock, 5 to 25 percent slopes.

LIMY SOILS ON VALLEY SLOPES AND HICH FANS

D1 Cundight-Cavelt-R1ll1to assoctation

Deep gravelly and shallow gravelly mediun-textured limy soils over cemented pans, 2 to 15 percent olopes.

D2 Laveen-Rillito association

Deep medium-textured and gravelly medium-textured, 11 my solls,

0 to 3 percene lopes,

ROCX LAVU

EI Cranle and schist Rock 1 and (arid and semiarld)

cranite and schist rock ouccrop and shallow, cobtly solls

In the arld and semlarid mountails.

E2 Andesite and basalt Rock land (arid and semiarid)

Volcanic rock outcrop and ahallow, cobbly aoils in the arld and semlarid mountalns.

E3] Andesice and basali Rock land (subhumid)

Shallow, cobbly soils and voleanic rock outcrop $\{\cdot$ the subhumid mountains.

E4 Cranite and schlot Rock land (subhumid)

cranite and schiet rock outcrop and shallow, cobbly soils in the oubhumld mountains.

MISCELLANEOUS

FI Rough broken land.

Areat of Rock land too mall to delineate becauge of map scale.

United Statee Department of Agriculture

soll Conservation Service

In cooperarton with

The Soll Conservation Diotricts in Pinal County

for

The Board of Supervisors of PInal Councy

Solle Information to derlved from general field

exemination and the ure of all avallable topo-

grephic and geologic mapo.

This map to intended for general planning only.

Each delineacion may contain solig difierent

from those shown on the map. Use detalled 01

mope for operational planning, and on-site

Inopection for more detalled declsiono.

Fig. 2.1

(Cont'd) 
texture or the chemical composition of the soils, but in getting adequate moisture to them. Figure 2.2 shows the typical soil associations in the Sacaton mine area.

\subsection{HYDROLOGICAL CONDITIONS AFEECTING OR AFFECTED BY THE OPERATION}

The area drains into the North Branch of the Santa Cruz Wash. Surface water resources are scarce and undependable. The water supplies for the mining operation and for irrigating the revegetated areas come from wells.

The mining operation has a total water consumptive demand of approximately 66.5 million gallons/month (205 acre-feet). The water is supplied. from 4 wells located approximately 5 miles east of the mine site. These wells are part of a 1280-acre farm that was purchased for the water rights. The land was then retired from agricultural production and the water was diverted for mine water in order to alleviate the ground water depletion that would otherwise continue if crops were still produced on this land.

The milling process, which consumes most of the water, reclaims and recycles approximately $75-80 \%$ of the water used. About one-fourth of the water is recycled from the tailing pond and $50-60 \%$ is recycled from other milling procedures. Most of the water actually consumed is lost to evaporation or is added to the tailings or ore concentrates that are shipped to the smelter. Water is the key to successful revegetation. Because of the very low and sporadic rainfall, irrigation is essential for the initial establishment of vegetation on the mine spoil. The irrigation consumes approximately 250,000 gallons/month $(0.77$ acre-feet), a consumptive rate that varies with the size of the revegetation areas covered, plant densities and size, and seasonal demands. The water received from the wells for irrifgation has a $\mathrm{pH}$ of 8.2 , and in ppm contains: $600 \mathrm{TSS}, 19 \mathrm{Ca}, 7 \mathrm{Mg}, 223 \mathrm{Na}, 130 \mathrm{Cl}, 290 \mathrm{~S}$, $6 \mathrm{~F}$, and $2 \mathrm{~N}$. The water reclaimed from the tailing pond, which could be a source of irrigation water, has a $\mathrm{pH}$ of 8.7 , and in ppm contains: 1064 TSS, $27 \mathrm{Ca}, 12 \mathrm{Mg}, 321 \mathrm{Na}, 98 \mathrm{cl}, 452 \mathrm{~s}, 12$ carbonate, 33 bicarbonate, $17 \mathrm{~F}, 28 \mathrm{~N}$, $1 \mathrm{PO}_{4}$, and $63 \mathrm{~K}$. Since the $\mathrm{Na}$ and $\mathrm{F}$ are excessively high, the reclaimed water could not be used as a source of irrigation water without treatment (McKee and Wolf, 1963).

\subsection{LAND USE AND OWNERSHIP PATTERNS}

Agriculture and mining are the two principal industries in the state. Most of the farms range from 320 to several thousand acres in size. Cotton is the principal crop, and other important crops are barley, grain sorghum, alfalfa, some melons, and citrus. There are several large cattle feeding operations in the area and winter grazing of sheep is common.

The total area that the copper mining industry occupies in the State of Arizona is only $0.14 \%$ of the total area of the state (Fig. 2.3). But, since the mines provide jobs and people move to centers of mining activity, urban development in these areas is increasing at a very fast rate. In addition, some of the reclaimed land near urban centers may be sulted for 


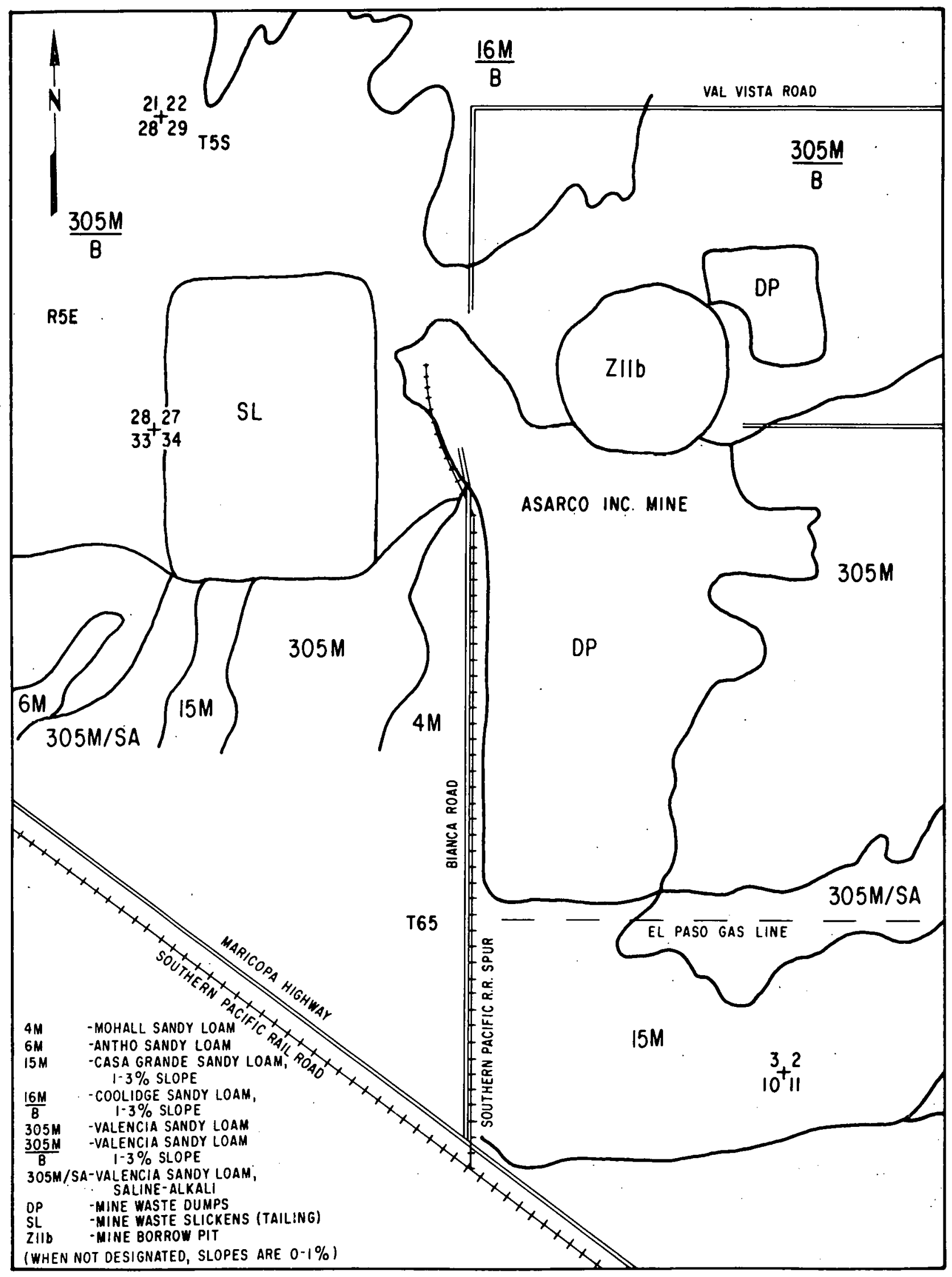

Fig. 2.2. Soil Associations of the Sacaton Mine Site 
Fig. 2.3. Mining Land Use in Arizona

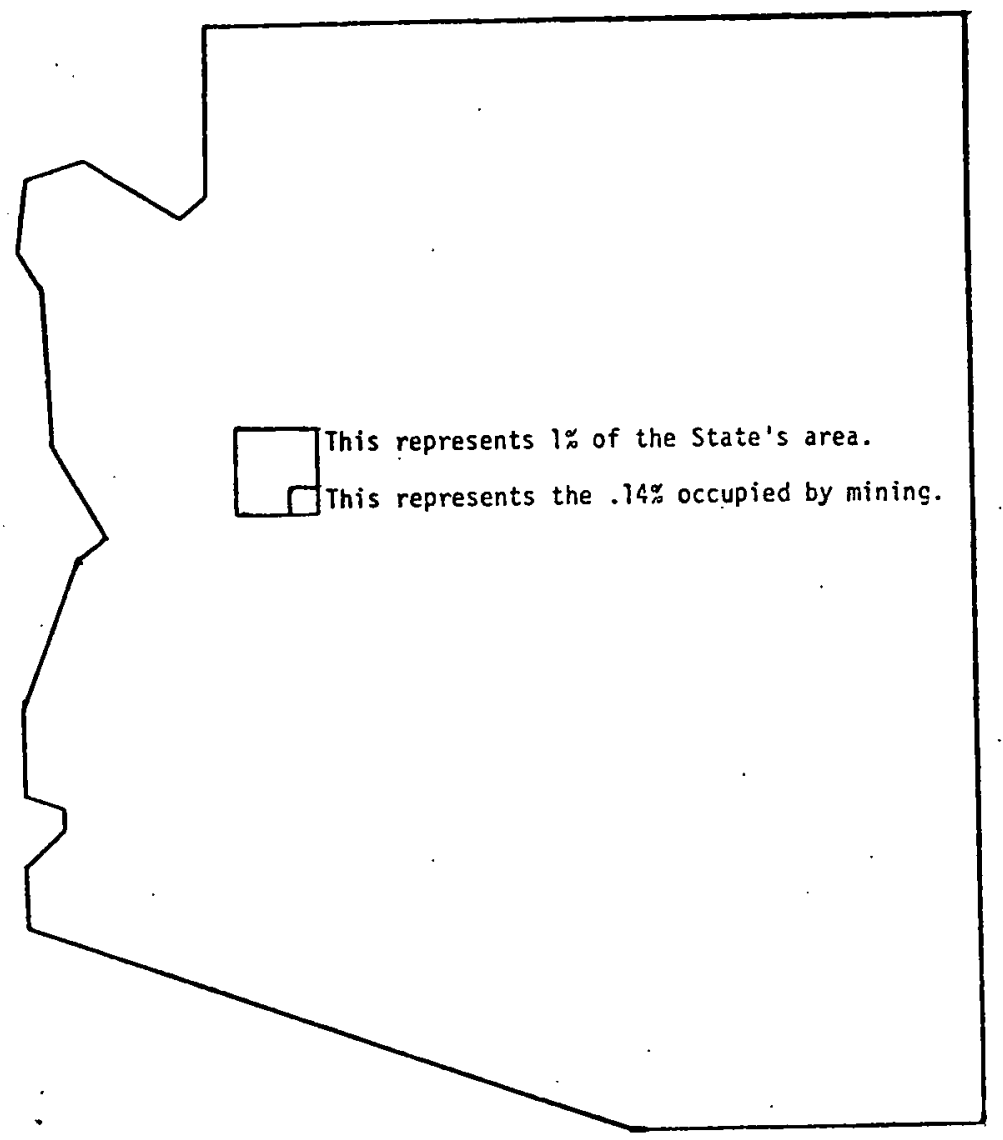

industrial and residential development. Even though only 100,000 acres out of a total of 73 million are affected by mining in Arizona, the $0.14 \%$ of state land exerts a proportion far beyond a real extent.

Prior to mining, the Sacaton mine land was in private and state ownership (Fig. 2.4). After the initial discovery, options were obtained from the property owners, and prospecting permits were secured on the state land: Most of the mine and dump areas are located on both private and state land. However, ASARCO owns most of the land associated with the Sacaton mining operation, aside from some scattered acreages in the area of stateowned land. Additional farmland five miles east of the plant site also had to be purchased to obtain water rights in order to assure a water supply for the operation.

The land use before the mining operation started was livestock grazing. Currently, the entire area of about four sections is fenced off and no grazing is allowed within the leased area. Because of the long-term operation of the open-pit mine, the ultimate use to which the land will be put after the mine closes is unknown. The reclamation plan calls for establishing vegetation, but acknowledges the long-range possibility of using the land for such other uses as housing sites and industrial development. 


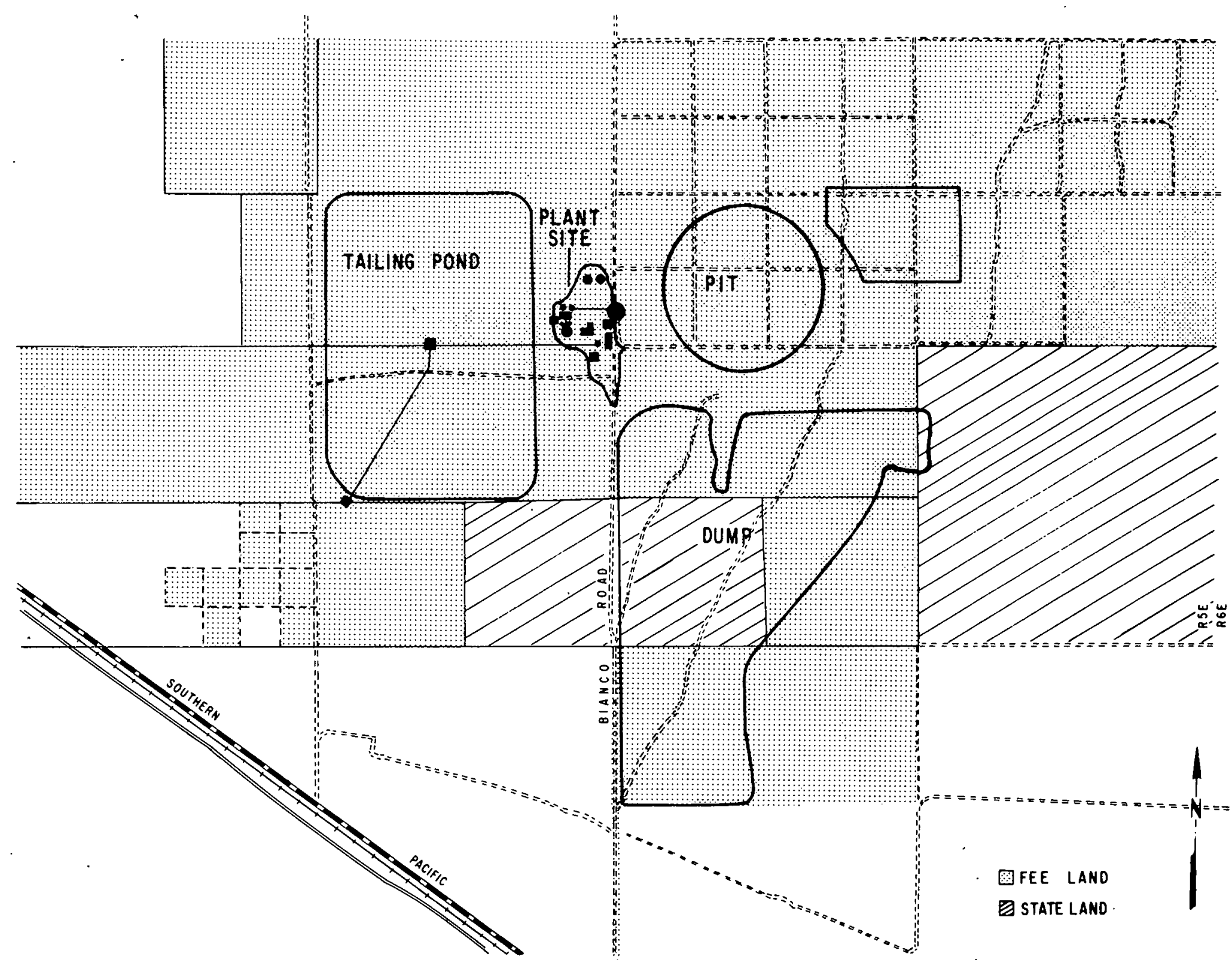

Fig. 2.4. ASARCO Sacaton Mine Land Ownership 
3 MINING DATA

\subsection{HISTORY OF THE OPERATION}

The Sacaton Mine is ASARCO's newest mine. It is also the most recently opened major copper mine in Arizona. The history of the mine is almost a textbook example of the discovery of a major deposit, development of the property for efficient production, and planning for moderating environmental impacts.

An inconspicuous low hill about $300 \mathrm{ft}$ in diameter, protruding from an alluvial valley and over a mile from the nearest bedrock outcrop, led to the discovery of the Sacaton ore body. The hill, composed of granite cut by a monzonite porphyry dike, contained pervasive senicitic and argillic alterations. Both rock types exhibited limonite derived from the oxidation of pyrite, and traces of limonite were derived from the oxidation and leaching of chalcocite (a copper ore mineral).

Geophysical surveys, including induced polarization, seismic gravity, and magnetics, were made of the area. Six drill holes were put down before a significant intercept of ore was made. Sixty-five holes, totalling 73,609 ft, were drilled during 1961 and 1962. Two ore bodies were delineated; however, the decision not to continue the work at that time was made on the basis of an economic analysis.

Coinciding with rising ccipper prices, a second drilling program was begun five years after the initial exploration to further delineate the two ore bodies. The program was completed in January 1969 after 38 additional holes had been completed. These comprised another 46,937 ft of drilling. Those data, combined with the results of the earlier program, were used to calculate the ore reserves. In order to further verify the feasibility of bringing the two deposits into production, metallurgical tests were run on 6 -inch diamond drill cores. A total of 38.2 tons of samples was collected from 15 holes. Ten drill holes totalling 15,017 ft were also drilled to obtain information about the strata located beneath the planned location of surface structures. On the basis of a feasibility study of drilling and market data, a decision was made in 1972 to proceed with mine development.

During May 1972, onsite preparations to mine the west ore body were begun. Soon after, a temporary headquarters and a field office were established. A fleet of equipment was leased to open the mine while the permanent equipment was being selected and acquired. Earthmoving began during May of 1972 with five scrapers, two water trucks, two track dozers, a rubber tired dozer, a motor grader, and a tractor. By the end of 1972, delivery and construction of the permanent equipment were completed.

A temporary electric power source was established at the site in October 1972, and surface mining operations began in 1973. By January 1974, 33.5 million tons of overburden had been removed and more than 300,000 tons of ore were stockpiled for the concentrator.

Thirteen years separated the time between the initial discovery and the beginning of production. However, after the decision was made to proceed 
with the mining operation, less than two years were required to bring the mine into production. The historical sequence of development is summarized in Table 3.1. The Sacation unit started production early in 1974.

With the Sacaton mine, the number of copper mines in Arizona totals 30. This total includes seven underground operations, two in-place leaching sites and 20 open-pit mines. The location and operations of these mines are shown in Fig. 3.1 and in the accompanying key.

The primary objective of the Sacaton mine is to supply copper ore of a profitable grade to the concentrator at a rate of 9000 tons per day. The cutoff grade for sulfide mineralization is $0.30 \%$ copper, with an average grade of $0.76 \%$.

Research is still under way to develop methods of concentrating an additional 2.8 million tons of oxide ore that is intermingled with the sulfide ore. Higher concentrating costs for oxide material may necessitate a higher cutoff for these ores.

The Sacaton unit (Fig. 3.2) has a work force of about 350 people recruited primarily from the immediate area of Casa Grande. The details of the land used by the operation are given in Table 3.2. The actual pit and subsidence areas occupy only about 640 acres of land (Fig. 3.3).

\subsection{OPERATING COMPANY}

ASARCO, Inc, is the sole operator of the Sacaton mine. In 1899, the company was organized as a consolidation of. several lead-silver smelting companies. Later, ASARCO evolved into an integrated mining, smelting, and refining operation for copper, lead, zinc, sliver and several by-product

Table 3.1. History of Development

\begin{tabular}{ll}
\hline \multicolumn{1}{c}{ Activity Sequence } & Date \\
\hline Initial Discovery & Feb. 1961 \\
First Drill Hole & Sept. 1961 \\
First Drill Program Terminated & Nov. 1962 \\
Initiation of Second Drilling Program & Jan. 1969 \\
Final Drilling Completed & May 1971 \\
Decision to Proceed with Project & Apr. 1972 \\
Preparations to Mine the West Ore Body & May 1972 \\
Lease of Temporary Equipment & May 1972 \\
Acquisition of Permanent Equipment & Aug. 1972 \\
Temporary Electric Power Source & Oct. 1972 \\
Last Shovel, Tractor and All Trucks in Service & Jan. 1973 \\
Ore Stockpiled & Jan. 1974 \\
Completion of Concentrator & Jan. 1974 \\
\hline
\end{tabular}


FIG. 3.1. LOCATION OF COPPER MINES IN ARIZONA AND ACCOMPANYING KEY 


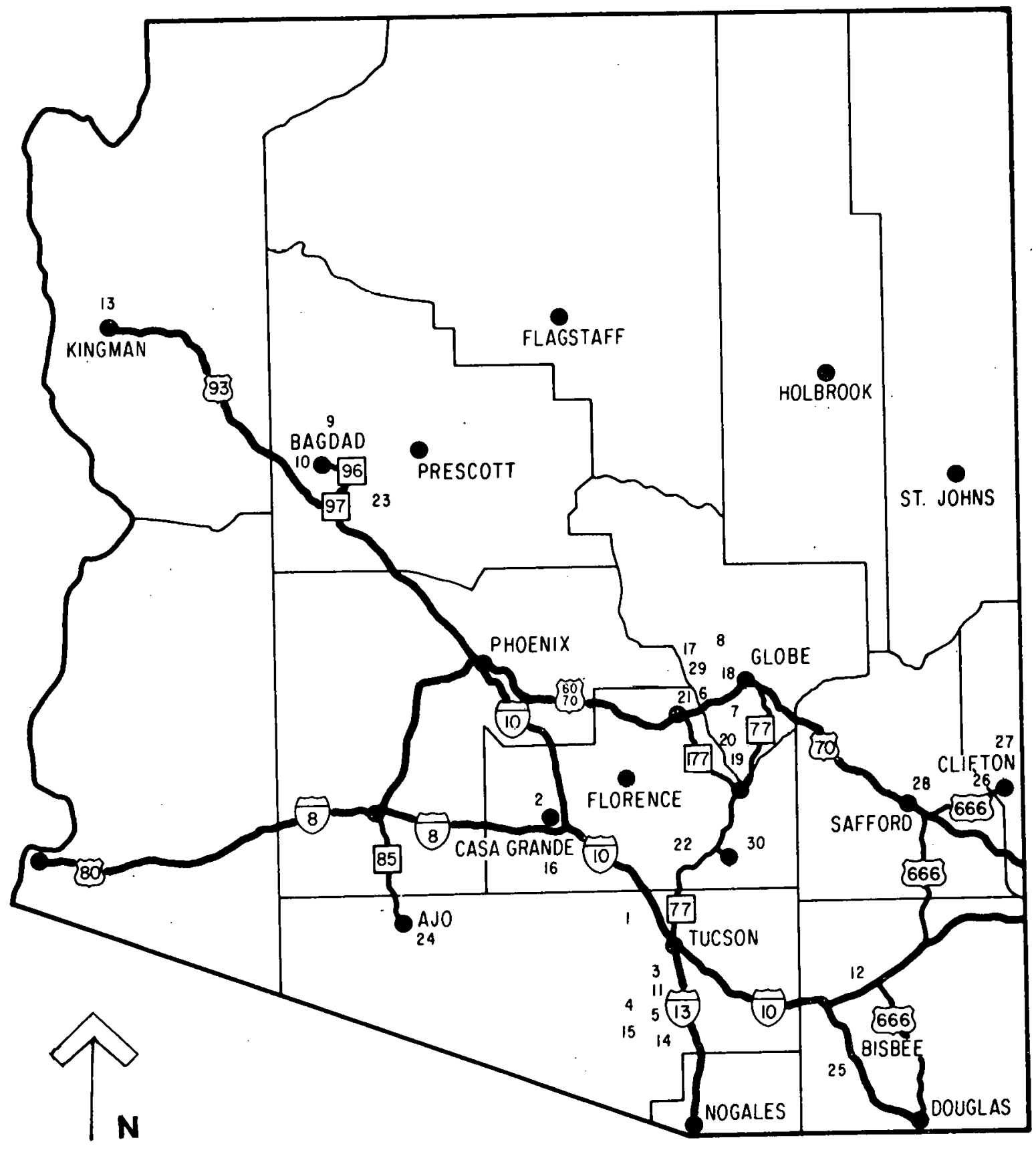

Fig. 3.1. Location of Copper Mines in Arizona 
KEY TO FIG. 3.1

\section{ASARCO INCORPORATED}

1. Silver Bell Unit, open pit mine northwest of Tucson

2. Sacaton Unit, open pit mine north of Casa Grande

3. Mission Unit, open pit mine south of Tucson

4. San Xavier Unit, open pit mine south of Tucson

ANAMAX MINING CO.

5. Twin Buttes Mine, open pit south of Tucson and the Anaconda Company in partnership with Amax Arizona Inc.

\section{CITIES SERVICE COMPANY}

6. Pinto Valley Mine, open pit west of Miami

7.. Miami East, underground mine development

8. Copper Cities Mine, open pit north of Miami

\section{CYPRUS MINES CORPORATION}

9. Bagdad Mine, open pit at Bagdad

10. Bruce Mine, underground mine west of Bagdad

11. Pima Mine, open pit south of Tucson

12. Johnson Mine, open pit deve1opment east of Benson

\section{DUVAL CORPORATION}

13. Mineral Park Mine, open pit north of Kingman

14. Esperanza Mine, open pit south of Tucson

15. Sierrita Mine, open pit south of Tucson

\section{HECLA MINING COMPANY}

16. Lakeshure Mine, underground development south of Casa Grande

\section{INSPIRATION CONSOLIDATED COPPER} COMPANY

17. Ox Hide Mine, open pit west of Miami

18. Thornton \& Live Oak open pit mines, north of Miami

19. Christmas Mine, open pit south of Miami

\section{KENNECOTT COPPER CORPORATION}

20. Ray Mine, open pit north of Hayden MAGMA COPPER COMPANY

21. Superior Mine, underground

22. San Manuel Mine, underground blockcaving

\section{MCALESTER FUEL COMPANY}

23. Zonia Mine, in-place leaching at Kirkland, southwest of Prescott

\section{PHELPS DODGE CORPORATION}

24. New Cornelia Mine, open pit at Ajo

25. Copper Queen Mine, underground at Bisbee

26. Morenci Mine, open pit

27. Metcalf Mine, open pit development near Morenci

28. Safford Project, underground development north of Safford

RANCHERS EXPLORATION \& DEVELOPMENT CORPORATION

29. Bluebird Mine, open pit west of Miami

30. Old Reliable Mine, in-place leaching northeast of San Manue1 


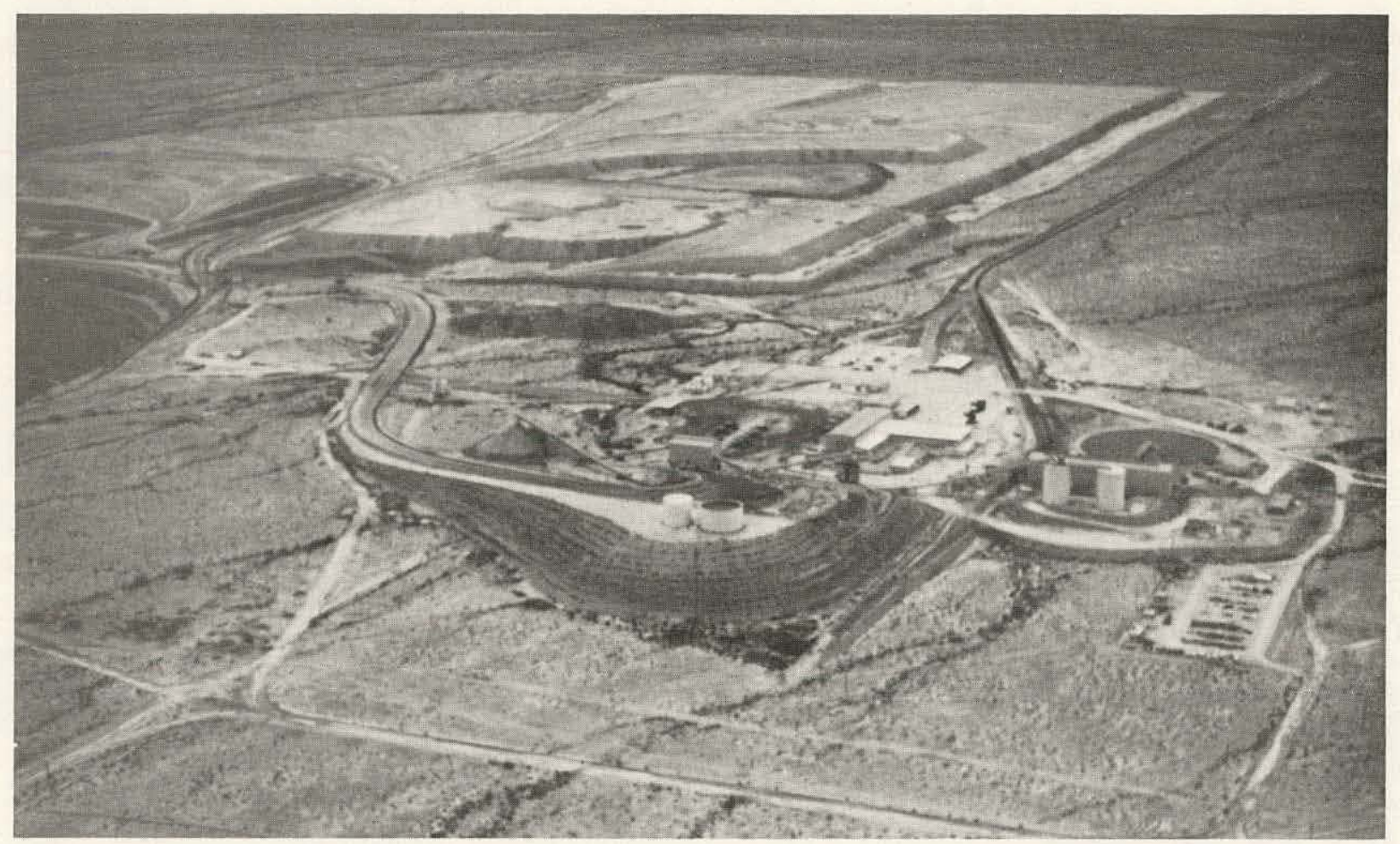

Fig. 3.2. Sacaton Mine Unit

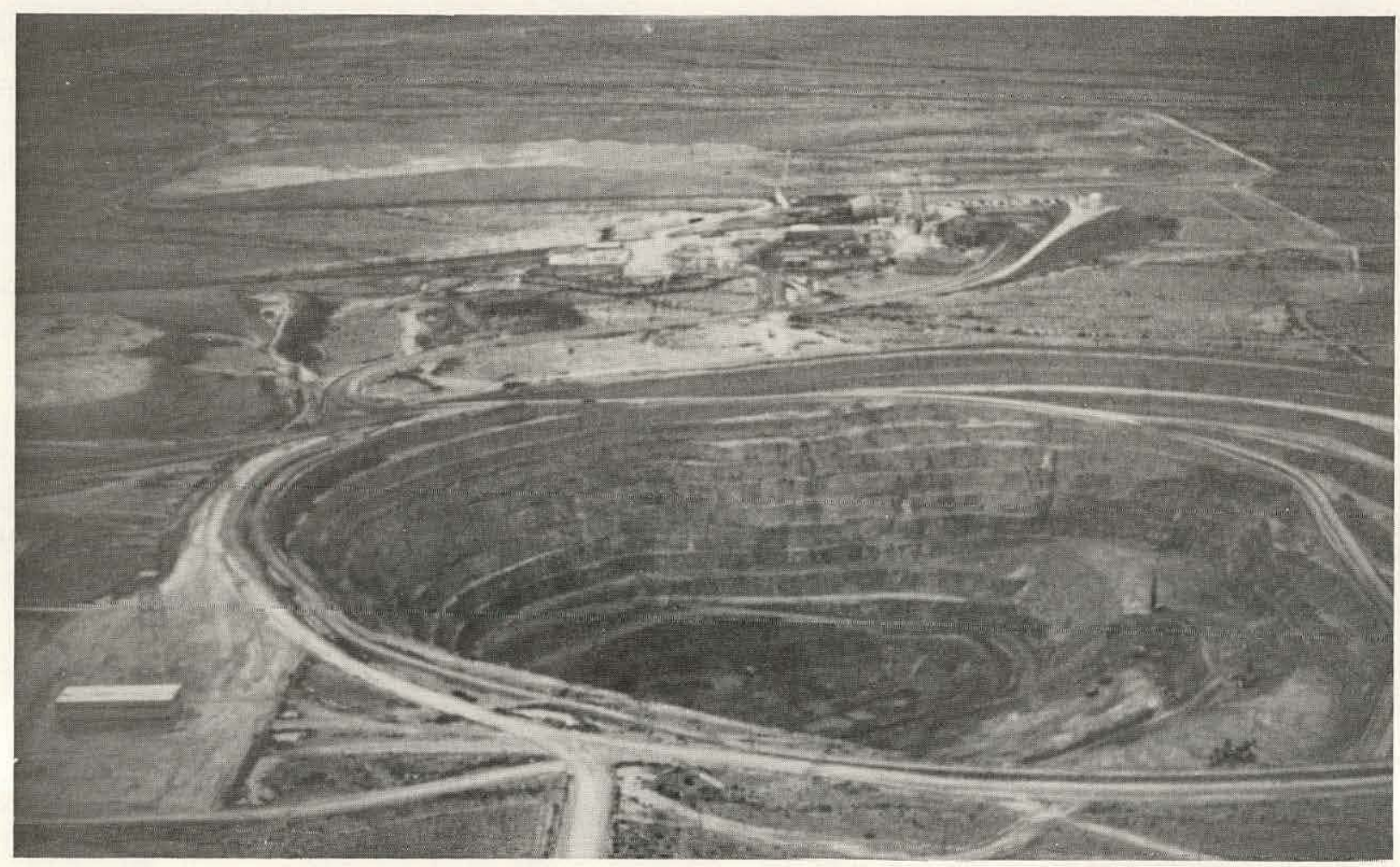

Fig. 3.3. Sacaton Mine Pit 
Table 3.2. Land Use by Sacaton Mine

\begin{tabular}{lr}
\hline \multicolumn{1}{c}{ Type and Use } & Acres \\
\hline Open Pit Site and Subsidence Area & 640 \\
Mill Site & 73 \\
Waste Dumps & 840 \\
Tailing Ponds & 450 \\
Buffer Zones & 980 \\
Water Farm & 1660 \\
Other & 1921 \\
$\quad$ TOTAL & 6564 \\
\hline
\end{tabular}

metals. It has also expanded into related fields such as the mining of coal, asbestos, limonite, sand, gravel, and limestone.

Custom smelting and refining ores mined by others, the original purpose of the company, remains an important part of ASARCO's operations. ASARCO is the only U.S. firm capable of processing certain complex ores and recovering products such as bismuth, arsmuth, and arsenic trioxide.

Since its founding, ASARCO's refineries have produced about 26 million tons of copper, 26 million tons of lead, 7 million tons of zinc, and 6 billion troy ounces of silver. Some of these metals have originated from ASARCO mines, but most were produced by other mining concerns and by ASARCo's associated companies in other countries. The company's history is shown in Table 3.3, and the Appendix includes a listing of ASARCO offices, mining properties, and associates.

\subsection{MINERAL RIGHTS}

The Sacaton mine is developed exclusively on privately-owned land. The area is surrounded by state-owned land on the north and by private lands to the south. The mineral rights, along with the land, were purchased by ASARCO before operations started. At present, ASARCO is exploring for copper deposits on adjacent state lands.

\subsection{LAND VALUES AND TAXATION POLICIES}

ASARCO purchased about 5595 areas of land and its mineral rights from the private owners. During the fiscal year of 1974, the land was assessed for $\$ 145,000$. The amount of tax (for land only) paid for the year 1974 was $\$ 5,800$.

\subsection{FUTURE DEVELOPMENT PLANS}

In the future, the underground and open-pit ores will be ready to be blended without interrupting the production schedule of 9000 tons of ore 
Table 3.3. History of ASARCO, Inc.

1899

1900-1909

$1910-1919$

$1920-1929$

$1930-1939$

1950-1959

$\cdot 1960-1969$

$1970-1974$
ASARCO organized. Included in original consolidation were mines and mining claims in Colorado and Mexico.

Merged with M. Guggenheim's Sons. Purchased control of Federal Mining and Smelting Company, which owned mining properties in Idaho. Acquired five additional mines in Mexico.

Purchased mining properties in Silver Bell district of Arizona.

Page mine in Idaho started up. Northern Peru Mining and Smelting Company organized. Buchan's mine in Newfoundland brought into production. Ground Hog mine in New Mexico opened.

Initial investment made in Australia's Mount Isa Mines Limited. Acquired interest in Neptune Gold Min̊ng Company in Nicaragua.

Production commenced at Silver Bell, ASARCO's first open-pit mine. Galena silver mine in Idaho started production. Lake Asbestos of Quebec, Ltd. began operations.

Southern Peru Copper Corporation opened Toquepala mine. Mission mine in Arizona started up. Mexican mines and plants organized into Asarco Mexicana, S.A. Page mine closed.

Granduc copper mine in British Columbia commenced operations. Midland Coal Company Division formed from four purchased Illinois mines. Leadville mine in Colorado began mining lead-zinc-silver ore. Four Tennessee zinc mines purchased. American limestone Company of Knoxville, Tennessee acquired. San Xavier copper mine and leach plant in Arizona started production. Manchester limonite mine in New Jersey started up. A partnership of Anaconda and ASARCO began development of Ontario lead-zincsilver mine in Utah with production slated for 1975. Copper mining began at Sacaton open-pit in Arizona 
dally. The underground orebody consists of approximately 15.5 million tons of primarily sulfide ore. The ore zone is about $1200 \mathrm{ft} 1$ long and $600 \mathrm{ft}$ wide, trending northeast, and is located $1000 \mathrm{ft}$ northeast of the open-pit orebody. The underground ore occurs at a depth of about 1500-1800 ft.

Present plans call for placing development workings in the bottom of the orebody. The mining method as now planned will be block caving, utilizing slusher drifts and direct train loading. This method will allow close vertical spacing between the draw or slusher level and the haulage level. Development so far includes a deep vertical shaft, collared to bedrock, a headframe, hoisthouse, and a used hoist in the process of being assembled. The shaft will be used to gain access to the orebody for exploration and final evaluation, and will then become the ore hoisting and service shaft for operation of the mine. A second shaft will be sunk for ventilation and will also serve as an emergency escapeway.

\subsection{COMMODITY DESCRIPTION}

The low grade of the copper in both deposits is dependent. on an incoming degree of enrichment. During the later stages of intrusion of the monzonite porphyry, primary sulfide mineralization of marginal grade was introduced into both the monzonite porphyry and the granite. Later erosion, oxidation, and enrichment formed two somewhat tabular-shaped bodies of chalcocite ore.

Primary sulfide mineralization in both deposits consists mainly of pyrite and chalcopyrite. In most of the primary zones, these sulfides occur in a volume proportion of about 1.5 parts pyrite to 1 part chaicopyrite. The total sulfide content (by volume) averages between $1.5-3.0 \%$. The primary sulfides occur both as thin veinlets and as discrete grains in roughly equal proportions. Chalcocite and minor covellite occur as supergene replacements of both pyrite and chalcopyrite. Chalcocite predominates in the upper portion of the ore zones and chalcopyrite in the lower. In addition to copper, the ore contains minor amounts of molybdenum and traces of gold and silver.

Leached capping, varying in thickness from 100-500 ft, overlies both deposits. The capping is characterized by the presence of live limonites derived from the oxidation and leaching of chalcocite. Copper values in the capping average less than $0.1 \%$ copper, except where appreciable amounts of parched sulfides or oxidized copper minerals are present. Deep post-enrichment oxidation and leaching has destroyed portions of the chalcocite blanket. oxidized copper minerals including antlerite, brochantite, azurite, malachite and chrysocolla are found in varying quantities in the capping and below where second stage oxidation has penetrated the sulfides. The two general types of ore, sulfide and oxide, average about $0.78 \%$ copper.

The deposits are two somewhat tabular-shaped bodies of chalcocite ore. The west deposit is about $1200 \mathrm{ft}$ in diameter and varies in thickness from less than 100 to more than $700 \mathrm{ft}$ in the center. The east deposit, lying at. a depth of $1500 \mathrm{ft}$, is about $600 \mathrm{ft}$ wide and $1200 \mathrm{ft} 1 \mathrm{ong}$, and about $300 \mathrm{ft}$ thick. The top of the west ore body was covered by approximately $250 \mathrm{ft}$ of alluvium, conglomerate, and barren rock. 
The ore bodies that lie within a zone of hydrothermal alteration measure 2.5 miles in length and up to one mile in width. Phyllite and argillite are the principal alteration types with stronger alteration generally coinciding with more abundant sulfide mineralization. Notable features include a paucity of quartz veining (generally less than $1 \%$ of the rock) and an abundance of specular hematite (up to 3 or $4 \%$ of the rock). The intensity of the alteration decreases outward from the ore bodies.

The combined ore reserve of both deposits is approximately 47.5 million tons. About two-thirds of the recoverable ore will come from the open-pit mine, with the remaining one-third from the underground mine.

\subsection{EQQUIPMENT}

The presence of two basic types of waste material in the overburden required the use of two different earthmoving systems. For the unconsolidated alluvium, dozers were used to rip the soil and to push load scrapers, which haul the material to the stockpile site. The equipment used for this operation is listed in Table 3.4; the equipment used to drill, blast, load, and haul the rock and conglomerate in the pit in Table 3.5; and the equipment for haul-road maintenance and dust control within the pit and dump areas in Table 3.6. Approximately 15 million tons of alluvium and 25 million tons of rock had to be removed before an adequate ore supply could be developed for the mill.

Table 3.4. Equipment Used in Stripping

\begin{tabular}{lllc}
\hline \multicolumn{1}{c}{ Machine } & Make & Model & No. in Use \\
\hline Dozer & Cat. & D8 & 2 \\
Dozer & Cat. & D9h & 3 \\
24-cu-yd Scraper & Terex & s-24 & 11 \\
\hline
\end{tabular}

Table 3.5. Equipment Used to Drill, Blast, and Haul Material

\begin{tabular}{llcc}
\hline \multicolumn{1}{c}{ Machine } & \multicolumn{1}{c}{ Make } & Model & No. in Use \\
\hline 9" Rotary Drill & Bucyrus-Erie & $45 \mathrm{R}$ & 2 \\
Rubber-Tired Dozer & Cat. & 834 & 1 \\
Rubber-Tired Dozer & Cat. & 824 & 1 \\
9-cu-yd Electric Shovel & P \& H & 1800 & 3 \\
12-cu-yd Loaders & Michigan & 475 & 2 \\
85-ton Haul Trucks & WABCO & $85 \mathrm{c}$ & 20 \\
\hline
\end{tabular}


Table 3.6. Equipment Used for Road Maintenance and Dust Contro1

\begin{tabular}{llll}
\hline \multicolumn{1}{c}{ Machine } & Make & Model & No. in Use \\
\hline 7000-gal. Water Truck & Cat. & $769-\mathrm{B}$ & 2 \\
8000-gal. Water Truck & Euclid & $201-\mathrm{TO}$ & 1 \\
Grader & Cat. & $14 \mathrm{E}$ & 2 \\
\hline
\end{tabular}

Three electric shovels, equipped with 9-cu-yd buckets, are used to remove the ore and waste. The material is loaded into WABCO $85 \mathrm{c}$ dump trucks having a capacity of 85 tons. A fleet of 20 is employed In the Sacaton mining operations. At the time a truck is loaded, the shovel operator informs the driver whether he is hauling ore or overburden. The ore is hauled one-half mile to the mill, whereas the overburden is hauled three-quarters of a mile to the overburden dump area. The mining operation, served by a source access road, is only a short distance from the main line of the Southern Pacific Transportation Company. The ore is processed in a mill located on the mine property that is designed to concentrate 9000 tons of ore per day. Primarily, the operation includes a coarse crusher, fine crusher, and a concentrating plant.

\subsection{PRODUCTION COSTS}

Precise estimates of cost of production are difficult, if not impossible, to make. The operation consists of mining and reclamation, milling, transporting, and final processing. The current mining costs are about 30 cents per ton of copper material or about $\$ 2.45$ per ton of copper ore. The direct milling costs vary from $\$ 1.16-\$ 1.20$ per ton. Final processing is done at the Hayden, Arizona, smelter and Amarillo, Texas, refinery.

\subsection{MINING METHODS}

The top of the main orebody was covered by approximately $250 \mathrm{ft}$ of alluvium, conglomerate, and barren rock. The rippable alluvium was removed with scrapers. Shovels and trucks are used to haul away the conglomerate and other rocks.

The mining plan calls for a 40-ft bench height with final slopes of $1: 1$ in rock and 1.25:1 in alluvium. During the life of the mine, an average of 52,200 tons per day, including 9000 tons of ore, will be removed from the pit on a three-shift-per-day, 356-day-per-year basis. This average tonnage figure is not representative of present operations, however, because of the large amount of waste that must be removed to gain access to the ore. Presently, as much as 90,000 tons of material per day is being removed from the pit.

The two basic excavating systems used during the stripping period also were utilized initially in the open-pit mining operation. They were capable 
of moving 100,000 tons of material during a 24-hour period. The 24-cu-yd scrapers were used to remove alluvium and whatever conglomerate they could successfully load. The remaining conglomerate and rock were drilled, blasted and loaded by the 9-cu-yd shovels or 12-cu-yd loaders into the 85 -ton trucks for haulage to the dump or concentrator. Approximately $60 \%$ of the material was being moved with the truck, shovel and loader fleet and the remainder handled with the scraper fleet. The scraper operation was phased out in 1975.

Since all the rock must be drilled and blasted before removal, blasting costs are a big factor. Blasting is accomplished with ammonium nitrate/fuel oil (ANFO) in dry holes and bagged slurry in wet holes. The ANFO is mixed onsite and delivered by means of a pneumatic drill truck. Drill holes are 9 inches in diameter and are drilled to a depth of $52 \mathrm{ft}$. Drilling is carried out on a three-shift, seven-day-a-week bas1s, whereds blasting is done on a single-shift, five-day-a-week basis.

On completion, the pit will be roughly circular, with a diameter of $3000 \mathrm{ft}$ at the rim and a depth of $980 \mathrm{ft}$. A total of about 191 million tons of ore and waste will have been removed during the lifetime of the Sacaton Mine.

\subsection{IMPORTANCE OF THE OPERATION TO THE LOCAL ECONOMY}

Copper mining is not only vital to the nation's welfare, but there is also a mutually beneficial relationship between the Sacaton Copper Mining Unit, the City of Casa Grande, Pinal County, and the State of Arizona. Approximately one out of every eight employees in the state is directly employed by the copper industry; one out of every eight dollars of personal income in the state is paid by the copper industry, and one out every four tax dollars comes from copper. Tables 3.7, 3.8, and 3.9 show the importance of the copper industry to state and local revenues.

The City of Casa Grande, which has a population of about 15,000, is located about six miles from the mining site. The city is currently experiencing a healthy economic boost from the mining operation. The development and operation of the Sacaton mine are contributing to the local economy in payrolls, purchases of supplies, taxes, and housing development.

The 350-man workforce at Sacaton has been mobilized predominately from the immediate area of Casa Grande. Since equipment and methods used on the project were completely new to virtually the entire workforce, a job training program has been carried on at Sacaton almost since its inception. The training is carried out on a daily basis by unit supervisory personnel with assistance from various vendors. 
Table 3.7. County Government Revenues Provided By the Arizona Copper Industry, 1970-1973

\begin{tabular}{|c|c|c|}
\hline \multirow[b]{2}{*}{ County } & \multicolumn{2}{|c|}{ Amount of Revenue ${ }^{a}$} \\
\hline & $\begin{array}{c}\text { Annual Avg. } \\
1970-72\end{array}$ & 1973 \\
\hline Pima & $\$ 7,820,808$ & $\$ 9,818,421$ \\
\hline Pinal & $2,092,936$ & $2,357,072$ \\
\hline Maricopa & $1,782,383$ & $2,363,571$ \\
\hline Gila & $1,512,685$ & $1,933,721$ \\
\hline Cochise & 481,711 & 515,694 \\
\hline Mohave & 358,257 & 273,238 \\
\hline Yavapai & 263,131 & 293,843 \\
\hline Coconino & 127,241 & 164,517 \\
\hline Yuma & 100,435 & 125,710 \\
\hline Graham & 69,030 & 38,585 \\
\hline Navajo & 66,314 & 89,849 \\
\hline Santa Cruz & 27,109 & 33,949 \\
\hline Greenlee & 24,736 & 269,536 \\
\hline Apache & 24,432 & 32,225 \\
\hline TOTAL & $\$ 14,751,208$ & $\$ 18,309,931$ \\
\hline
\end{tabular}


Table 3.8. Arizona State Government Revenues Provided by the Copper Industry, 1970-1974

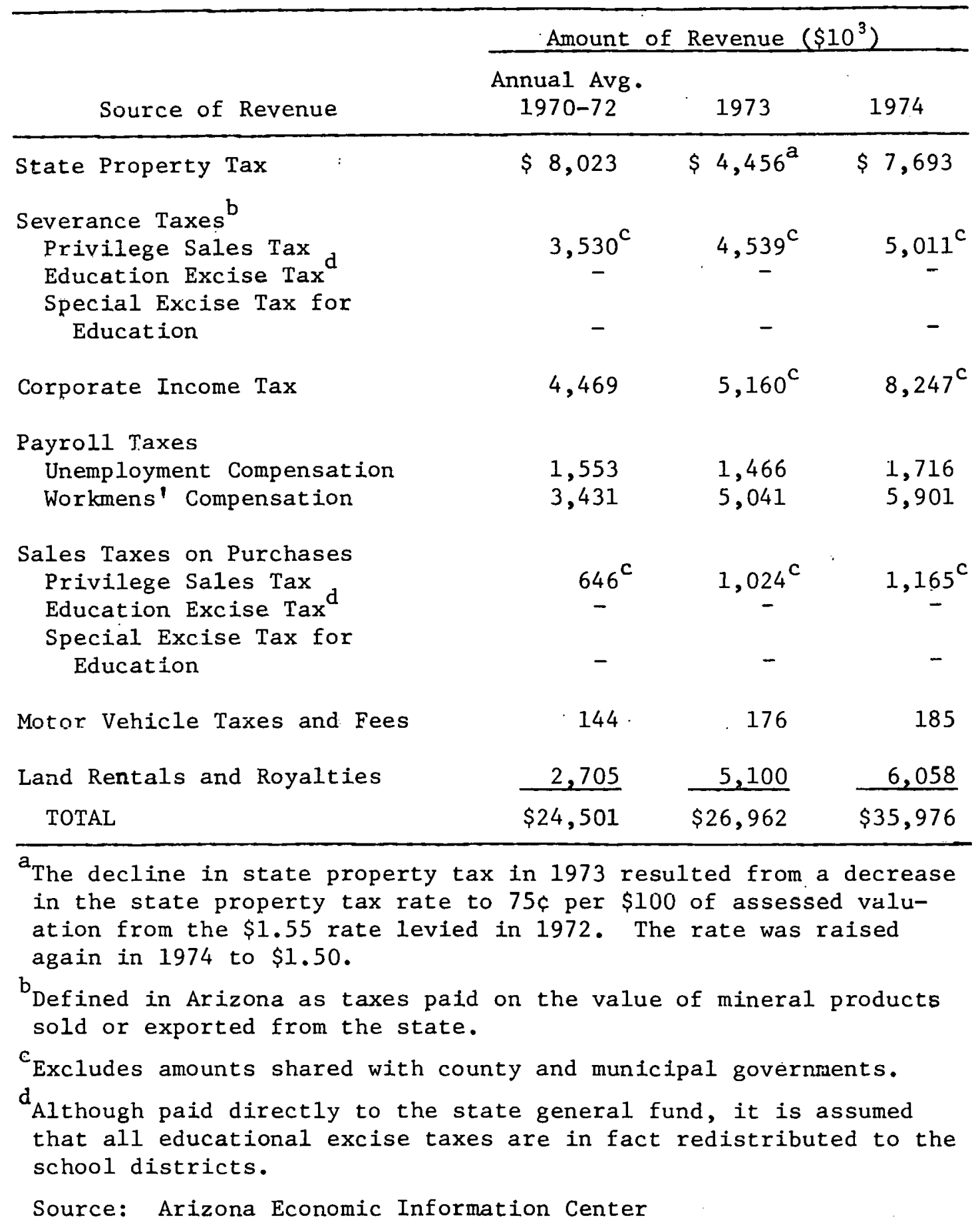


Table 3.9. Total State and Local Government Revenues Provided by the Arizona Copper Industry, 1970-1974

\begin{tabular}{|c|c|c|c|}
\hline \multirow{2}{*}{ Type of Revenue } & \multicolumn{3}{|c|}{ Amount Pald $\left(\$ 10^{3}\right)$} \\
\hline & $\begin{array}{c}\text { Annual Avg. } \\
1970-72\end{array}$ & 1973 & 1974 \\
\hline Property Taxes & $\$ 31,747$ & $\$ 34,998$ & $\$ 38,960$ \\
\hline $\begin{array}{l}\text { Severance Taxes } \\
\text { Privilege Sales Tax } \\
\text { Education Excise Tax } \\
\text { Specidl Excise Tax for } \\
\text { Education }\end{array}$ & $\begin{array}{l}8,527 \\
4,263\end{array}$ & $\begin{array}{r}10,963 \\
5,481 \\
5,482\end{array}$ & $\begin{array}{r}12,105 \\
6,052 \\
8,517\end{array}$ \\
\hline Corporate Income Tax & 4,469 & 5,901 & 9,729 \\
\hline $\begin{array}{l}\text { Payroll Taxes } \\
\text { Unemployment Compensation } \\
\text { Workmens' Compensation }\end{array}$ & $\begin{array}{l}1,553 \\
3,431\end{array}$ & $\begin{array}{l}1,466 \\
5,041\end{array}$ & $\begin{array}{l}1,716 \\
5,901\end{array}$ \\
\hline Miscellaneous Taxes ${ }^{b}$ & 4,820 & 7,596 & 11,445 \\
\hline Land Rentals and Royalties & 2,705 & 5,100 & 6,058 \\
\hline TOTAL & $\$ 65,778$ & $\$ 82,028$ & $\$ 100,483$ \\
\hline \multicolumn{4}{|c|}{$\begin{array}{l}\text { a Defined in Arizona as taxes paid on the value of mineral products } \\
\text { sold or exported from the state. } \\
\text { b Includes sales taxes paid on Arizona purchases as well as motor } \\
\text { vehicle licenses and fees. } \\
\text { Source: Arizona Economic Information Center }\end{array}$} \\
\hline
\end{tabular}


THIS PAGE

WAS INTENTIONALLY

LEFT BLANK 


\section{PROCESSING}

\subsection{LOCATION AND SIZE OF FACILITIES}

The Sacaton copper mine is located about six miles northwest of Casa Grande, Arizona (Fig. 4.1). The facilities include two grinding mills and a concentrator.

In order to meet the basic design capacity for the concentrator, three shifts per day, seven days per week are required throughout the year to keep the concentrator operational at optimum levels. Assuming an equipment availability of $95 \%$, this estimate results in a design capacity of 9473 tons per day for the Sacaton mine.

The fine-crushing plant is designed for three shifts per day, seven days per week to maintain the ore requirements for the concentrator. The coarse crusher, fine crusher, and concentrator utilize central control locations and all assume a 6-1/2-hr operating time per shift. The fine-crushing capacity is rated at 475 tons per hour.

To meet the design tonnage, the coarse-crushing facility was designed to operate with two shifts per day, seven days per week; a continuous operation is needed to keep up with ore requirements in the concentrator. This schedule requires a coarse crushing capacity of 730 tons per hour, again assuming a 6-1/2-hr concentrator time per shift, utilizing central control locations.

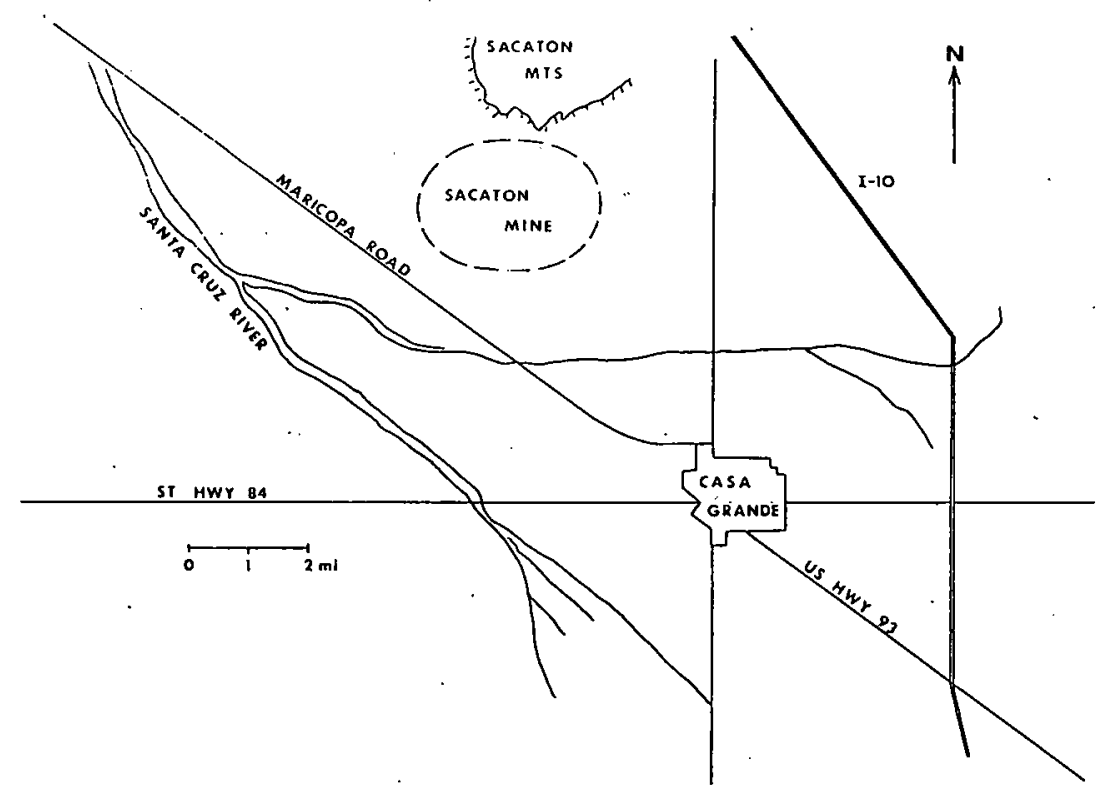

Fig. 4.1. Location of the Sacaton Copper Mine 


\subsection{TYPE OF OPERATION AND FINAL PRODUCT}

Coarse crushing is accomplished with a 48 x 60-inch jaw crusher set at 6 inches to enable the fine crushing feed to be approximately $45 \%$ less than 1-1/2 inches. The coarse crusher is in open circuit to allow for the use of an intermediate-storage surge pile. The coarse crushing circuit consists of a 165-ton-capacity ore receiving bin fed by 85-ton-capacity rear-dump ore trucks. A chain curtain inside the bin allows the ore to feed slowly onto a 6-1/2-ft wide by 24-ft-long, vibrating-pan grizzly feeder. Approximately $40 \%$ of the mine-run ore passes through the 6-inch openings in the grizzly while the remainder is crushed in the jaw crusher.

Both the grizzly undersize and crusher discharge are collected on a 42-inch conveyor belt and are discharged at the head pulley in the intermediate storage area. The resulting surge pile, approximately $70 \mathrm{ft}$ high, provides 4750 tons of storage for the fine-crushing plant.

The fine-crushing plant is laid out in closed circuit to ensure a consistently sized feed for the ball mills. Four remotely controlled vibratingpan feeders, located in a reclaim tunnel under the intermediate surge pile, feed onto a 42-inch conveyor belt. This belt, which conveys the ore past an electro-magnet, weightometer, and metal detector, feeds onto a 6 x 16-ft, single-deck vibrating grizzly screen. Approximately $40 \%$ of the ore passes through the 1-1/2-inch grizzly openings. The screen oversize passes into a 7-ft standard cone crusher. The crusher, set at 1 inch C.S.S., discharges onto a conveyor belt carrying the screen undersize product to the final screening tower where it discharges into a surge bin. This bin, with a capacity of 200 tons, is divided into two compartments, each of which discharges onto a 72-inch wide variable speed belt feeder. Each belt feeder supplies the feed for one of two $8 \times 20-f t$, single-deck vibrating screens.

Final screening is accomplished through $1 / 2$-inch-square-mesh screen cloth at an estimated efficiency of $85 \%$. Screen undersize from both screens combines on a 36-inch collecting belt and is conveyed to either of two fineore bins, each with a capacity of 3250 tons. A flopgate mechanism is used to divert the feed from one bin to a short conveyor belt feeding the other bin.

The screen oversize from both screens combines to make up the tertiary crusher feed. The screen oversize is carried, by way of a 36-inch conveyor belt, to a 7-ft shorthead cone crusher set at $1 / 2$ inch C.S.S. The crusher discharge combines with the standard crusher discharge and grizzly screen undersize to close the circuit.

Five wet-slurry-type dust collectors are located throughout the crushing plant at major transfer points. A single dry-bag-type dust collector, located atop one of the fine-ore bins, controls the dust at transfer points in the bin-top areas.

The primary grinding circuit, containing two 15-1/2-ft diameter by 18-ft-overflow ball mills, is typical of most single-stage grinding designs. Each of the ball mills, driven by a motor-clutch reducer-pinion drive arrangement, is in closed circuit with six 20-inch, rubber-lined cyclones and is automatically fed by three variable-speed belt feeders located under each of the fine-ore bins. 
A variation from previous methods of classifying middling products for regrinding has been incorporated in this circuit. Flotation middling products are classified in a cluster of three 20-inch, rubber-1ined cyclones. The cyclone overflow product is thickened for subsequent treatment in the cleaner flotation section and the underflow enters the regrind circuit as regrind cyclone feed.

The flotation circuit consists of a 10-inch, rougher feed motorized distributor feeding two identical banks of rougher flotation cells. Each bank is made up of twelve 300-cf, flotation cells. Automatic pump-1evel controllers are used at the junction and tail boxes in each bank. The recleaner-cleaner-scavenger circuit consists of three banks of thirteen 100-cf, forced-air cells.

The basic design includes horizontal rubber-lined pumps for all main slurry flows (with exception of primary cyclone feed) and vertical rubberlined pumps for all flotation froth products. Middling products are thickened in an automatic 1ift, 100-ft-diameter thickener and pumped by means of a variable-speed pump to the cleaner flotation circuit.

The copper-concentrate thickener, also designed with an automatic-1ift mechanism, is $75 \mathrm{ft}$ in diameter. Concentrate is metered from the thickener with a duplex diaphragm pump and is transferred to the filter system by means of a vertical slurry pump.

\subsection{TRANSPORTATION AND STORAGE SYSTEMS}

The concentrate is filtered by two $10-\mathrm{ft}$ diameter by $12-\mathrm{ft}$ drum filters, discharged onto a collecting conveyor belt, transferred to a loadout conveyor belt and deposited directly into a waiting railroad car. A 200-ton track scale supporting the railroad car is used to insure proper loading of the car.

Southern Pacific Transportation Company transports most of the materials out of the Sacaton mine. It hauls all the copper ore and concentrate from Sacaton to Hayden and from Hayden to Amarillo.

The Southern Pacific has 100-ton air-dump gondala cars to meet the special needs of the Arizona copper industry. These gondola cars have floors resembling big steel trap doors that are operated by air pressure. When the copper comes from the processing mill, it is powdery, fine, and moist and is in concentrated form. Previously, if the concentrate loads dried out, they sometimes solidified and became extremely difficult to empty from the conventional rail cars. After the concentrate is loaded into these special cars, the surface is sprayed with a mixture of water and liquid plastic to keep it from blowing over the countryside.

The Sacaton copper mine area is drained by the North Branch of the Santa Cruz Wash. Runoff rates from the spoil piles and the construction areas are quite high during the summer rain storms. There is no drainage from the tailings pond. 


\subsection{EFFLUENTS}

Tailings are a finely-ground rock slurry from which most of the copper has been removed. Final tailings are thickened in a peripheral-drive, 275ft-diameter thickener. Since the area has little relief, tailings thickener underflow must be lifted approximately $30 \mathrm{ft}$ in elevation before it can be discharged at the tailings impoundment area. This is accomplished by piping the thickened slurry directly to a pump at the underflow level, which in turn is connected in series with another pump at ground level about $30 \mathrm{ft}$ above the first-stage pump (Fig. 4.2). Density and flow control of the tailings slurry can be maintained by controlling the speed of the second-stage pump.

Fresh water is obtained from four wells on the farm purchased for water rights. The water is pumped to a head tank, located near the property, which provides all of the fresh water for the operation. Reclaimed water, collected from the thickener overflows and tailings decantation, is combined in a reservoir, where it is treated with sodium hexameta-phosphate to minimize scale deposition in process piping. It is then returned to the mill for reuse. The recovery of process water is maximized to hold fresh water requirements to a minimum.



Fig. 4.2. Piping of Thickened Slurry 
Treatment of sulfide ore follows standard practice. Grinding $50-55 \%$ less than 200 mesh is performed with $2.01 \mathrm{~b} /$ ton lime $(\mathrm{pH} \mathrm{10.8)}$ and $0.021 \mathrm{~b} /$ ton A-238. Prior to flotation the pulp is treated with $0.02 \mathrm{lb} /$ ton $\mathrm{Z}-6$ and 0.06 $1 \mathrm{~b} /$ ton frother. Stage addition of reagents is performed as necessary during flotation. Treatment of the oxide ore is essentially the same as in the sulfide mode.

High amounts of sediment in the runoff water from the dumps and construction sites have been observed, although toxic elements are not leached from the site. Blowing dust from the spoils and tailings is also a major pollution problem. Tailing materials do not react as normal soils, since they are low in water-holding capacity, devoid of plant nutrients, and po1luted with excessive salts and heavy metals. In preparation for reclamation, each site must be evaluated to identify the nature and extent of these pollution problems. 


\section{THIS PAGE}

\section{WAS INTENTIONALLY \\ LEFT BLANK}




\section{MARKETS}

\subsection{LOCATION}

The Sacaton unit produces the copper ore concentrate, which is then hauled to the Hayden smelter by the Southern Pacific Transportation Company. The copper concentrate is shipped to ASARCO's Amarillo, Texas, facilities for further processing into copper products in the form of bars, anodes, and coiled rods. Final product shipments are handled through the company's New York clearing house for domestic as well as foreign markets.

\subsection{MARKET RELIABILITY AND FLUCTUATIONS}

The domestic and foreign markets for copper ore are extremely volatile because numerous national and worldwide economic trends affect copper production. Historically, the copper industry has been notoriously cyclical. In times of rising economic activity, prices have been strong and sales have readily absorbed the entire primary production of the free world. When economic activity weakens, however, copper producers have frequently experienced sharp declines both in the volume of their sales and in the prices they receive for their products. During weak periods they have had to contend with sharp increases in unsold inventories.

The principal copper exporting countries are banded together in an organization known as CIPEC. In the beginning only four countries participated in CIPEC -- Chile, Zambia, Zaire, and Peru -- but it is known that discussions have been held with some of the other copper exporting countries, such as the Philippines, Papua-New Guinea, Australia, and Canada, regarding their adherence to the scheme. The four CIPEC countries account for about $37 \%$ of free world mine production of copper. However, their share of the international copper trade is much greater as their domestic consumption is limited and virtually all their copper is exported.

The United States is not heavily dependent on the copper output of the CIPEC countries. United States copper mine production accounts for $90 \%$ of this country's primary copper requirements. Only about $4 \%$ of its total requirements, or about $40 \%$ of its copper imports, originate from the CIPEC countries. However, any CIPEC action toward the control of the copper market elsewhere also affects the copper market here. Experience during repeated periods of copper shortage during the last 25 years has demonstrated conclusively that the U.S. market cannot be isolated from the world market, despite this country's greater self-sufficiency in copper than that of its industrial competitors in Europe and Japan.

\subsection{COMPETITION}

Copper mining is a highly competitive industry. The nature and scope of competition is worldwide. The size and quality of the copper ore deposits play a significant role in the development and operation of new mines. 
Each of the four CIPEC countries has taken steps to control the marketing of its copper production. Fifteen years ago marketing was largely in the hands of private companies based in the United States, the United Kingdom, and Belgium. Shortly after the concerted action by Arab oil nations in 1973 to reduce output and embargo shipments to certain destinations, President Mobuto of Zaire was quoted as indicating that talks were being held between the Arab leaders and his government regarding future Arab assistance that would enable copper producers to maintain prices at remunerative levels. The possibility of Arab financial help was mentioned for the establishment of a stockpile of CIPEC copper should surpluses develop and prices start to weaken.

Known copper reserves in the world are large. Eight to ten major deposits have been drilled out but are not yet being equipped for production because of financing or political problems. There is a long lead time in bringing these deposits into production. However, any plan that puts a floor price under copper will surely stimulate the financing of such projects, particularly in areas outside CIPEC control.

High prices will also provide incentives for still more intensive recycling of coppex. In the past, the view has frequently been expressed that high prices for copper stimulate substitution, but is now less firmly held because of the shortage of some competitive materials.

Traditionally, copper prices overseas have been higher than those quoted domestically. And that disparity has afforded the U.S. copper firms somewhat of a shield against their foreign competitors. However, during the summer of 1974 , that situation reversed itself when the overseas quotes dipped below the domestic prices.

\subsection{FRICES}

Copper prices represent a highly sensitive economic index, and stockpiles in the U.S. and recorded in London affect them. Recently, the stockpiles in the London Metal Market were at a historically high.level, and those in the United States are also at a near record-high level. However, the price trend for the last two to three years has been quite unsteady.

During the spring of 1975, copper prices fell and the demand for the metal declined at a nearly unheard of pace. The reduced price was attributed to an oversupply caused by the slumping trend in the world economy. The major consumers of copper in both the United States and abroad -- the auto and home-building industries -- sliced their orders to a fraction of former levels. In 1976, domestic prices were about $75 \mathrm{c} / 1 \mathrm{~b}$ with the London Metal stock quoting a price of about $\$ 1.50$.

Copper prices on the world market peaked at $\$ 1.52 / 1 \mathrm{~b}$ in April of 19.74, a time when U.S. producers were quoting 68 cents. Two months later the domestic price peaked at 86 cents, but the overseas price had fallen to $\$ 1.23$. Arizona's copper producers posted sharply lower earnings for the last quarter of 1974, but showed moderate gains for the year as a whole. 


\subsection{SPOILS}

The extent to which land disturbed by copper mining can be reclaimed depends, in part, upon the characteristics of the spoil materials. The spoils consist of a mixture of overburden materials (Fig. 6.1). The materials, removed from the excavation of the open pit, are composed of alluvial soils, loosely consolidated granitic conglomerates and various other rock wastes. The spoil piles are deposited as flat-top benches, that have a maximum local relief of approximately $50 \mathrm{ft}$, with each successive bench offset about $200 \mathrm{ft}$ from the edge of the lower bench (Fig. 6.2). The material, which is allowed to assume its natural angle of repose, forms a slope of approximately 1.5:1. This usage provides the greatest structural stability while maximizing efficiency for the area required for waste disposal. The edge of the berms are sloped inward to prevent runoff from spilling over the edge and to avoid water erosion on the slopes. The alluvial overburden material has a pH of 8.5-8.8; 9-20 sodium of $\mathrm{PO}_{4}, 297-801 \mathrm{Na}, 22-45 \mathrm{Ca}$; and is of a coarse loam texture $(62 \%$ sand, $20 \%$ silt, $18 \%$ clay). The conglomerates have a pH of 7.3 ; 8 sodium exchange percentage; in ppm contain: $1463 \mathrm{TSS}, 33 \mathrm{NO}_{3}, 13 \mathrm{PO}_{4}, 306$ $\mathrm{Na}, 27 \mathrm{Ca}$; with a sandy texture (71\% sand, $18 \%$ silt and $11 \%$ clay). These overburden materials are segregated according to their texture, and fine alluvial and conglomerates are used to bury and cap over the rock wastes. This procedure provides a good growth medium for revegetation on the slopes. The alluvial material is also segregated and stockpiled for future use as a capping material for tailings and other waste materials.

Irrigating plants in tailings and other waste materials is critical to reclamation planning. The frequency of irrigation depends upon a number of factors such as the need of the particular plant, the season, the weather and the nature of the spoils. But, in any case it is important to moisten the entire root zone, and to maintain a desirable ratio of air and water to reclamation plants.

\subsection{REFUSE AREAS}

The talling wastes from the milling of copper ore are transported to the tailing disposal pond as a water slurry. A 370-acre tailings dam and facilities for distribution of tailings and the recovery of water were constructed during the summer and fall of 1973. As the tailings are discharged into the pond, the sandy material settles out and the water is decanted off, collected in a reclaim pond, and recycled. The coarse sands, which settle out near the edges of the pond, are used to build the dam face higher. Each successive lift is approximately $30 \mathrm{ft}$ in elevation with a slope of about 1.5:1. Finer tailing material, which settles out slowly, helps to seal off the pond at the bottom to prevent any tailing water seepage deep into the ground. The material is highly erosive and also subject to piping. The tailings contain a high amount of salts, which often precipitate to the surface and form a durable armor crust. The tailing materials have a pH of 5 or lower; 15 sodium exchange percentage; and in ppm contain: 5208 TSS, $23 \mathrm{NO}_{3}$, less than 1 of $\mathrm{PO}_{4}, 1026 \mathrm{Na}, 216 \mathrm{Ca}, 1660 \mathrm{Cu}, 59 \mathrm{Mg}$, and $2 \mathrm{Fe}$. These 


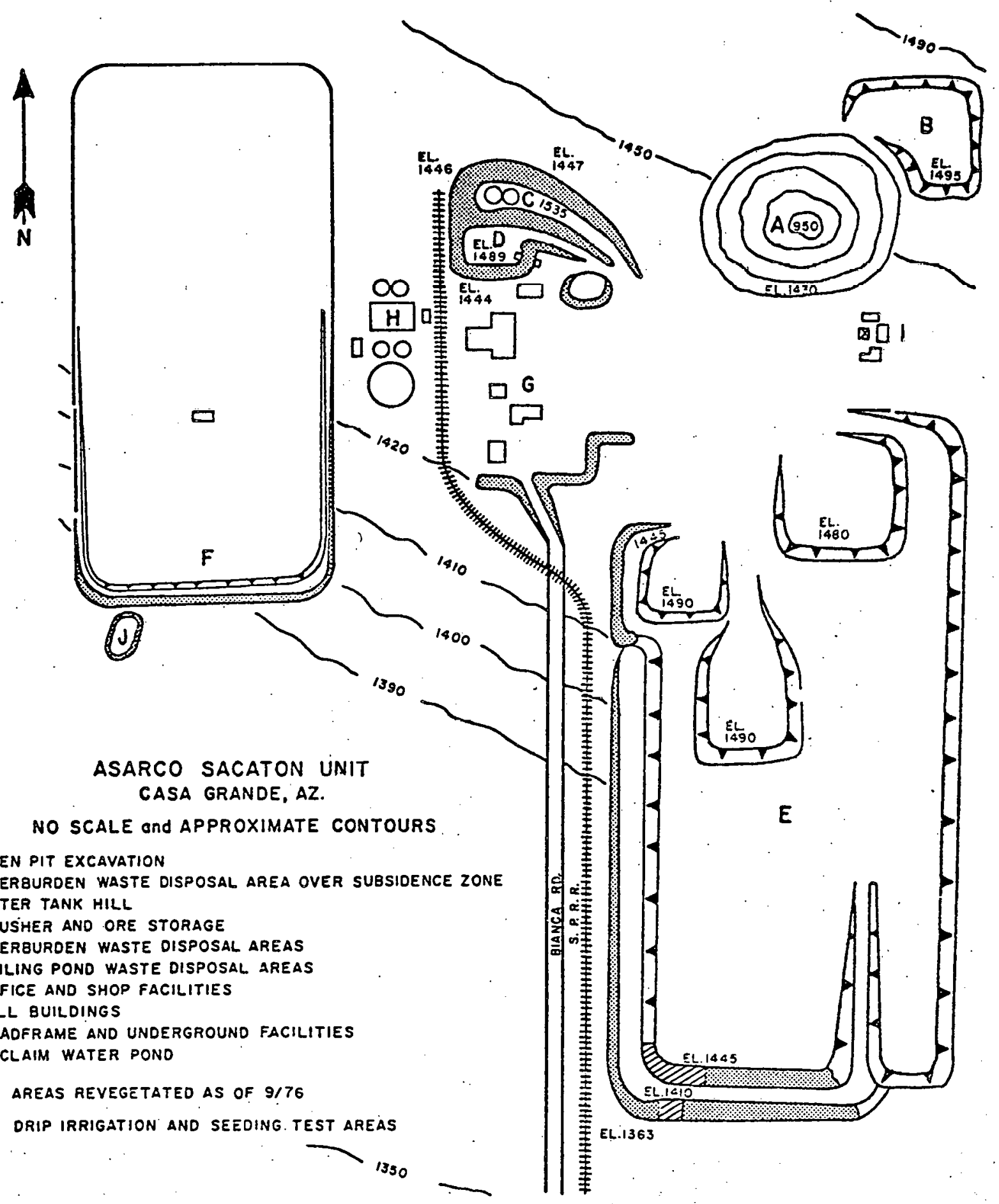

Fig. 6.1. Reclamation at the Sacaton Copper Mine 


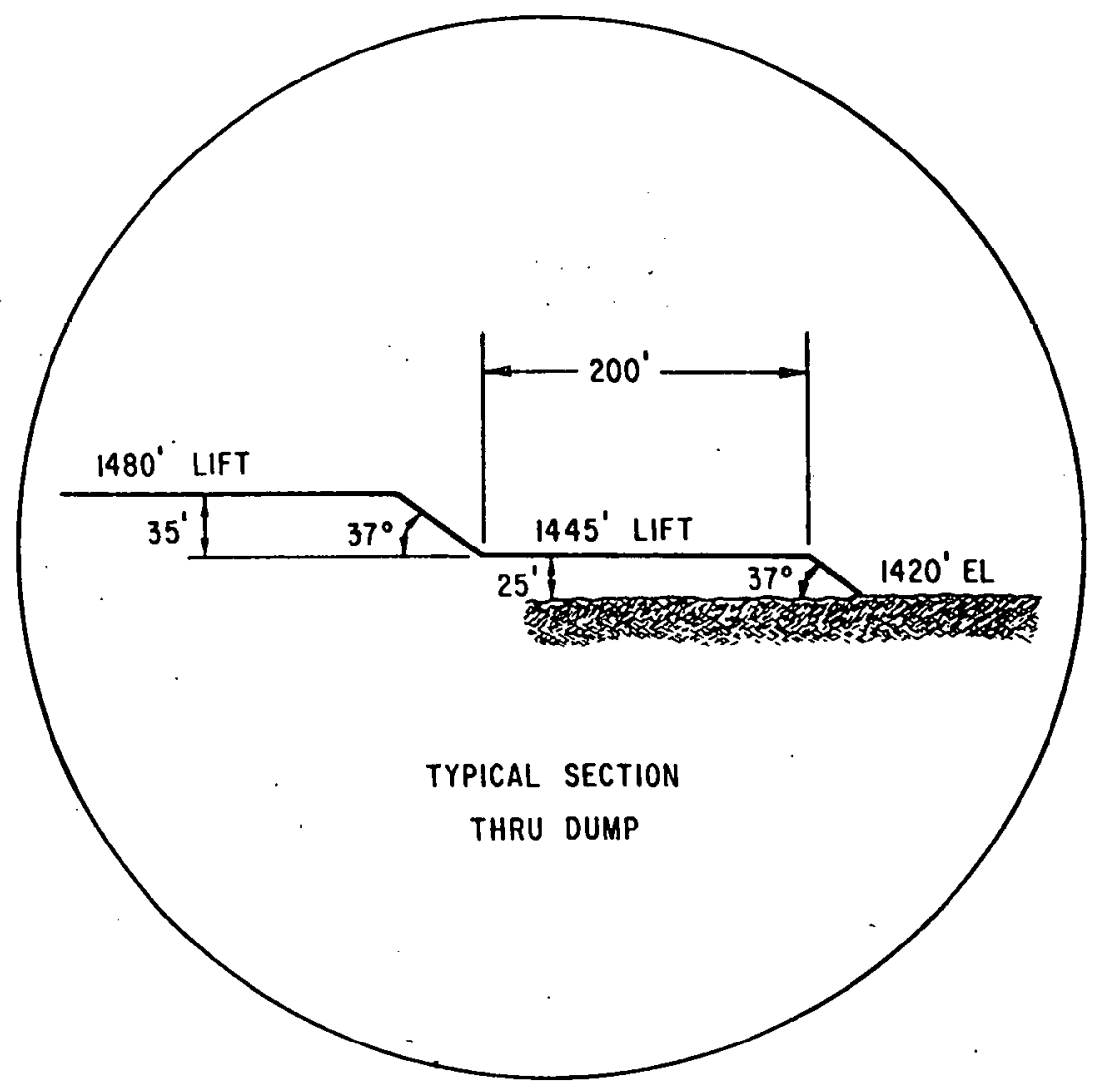

Fig. 6.2. Flat-'lop Spoil Benches

data reveal the tailings to be high in $\mathrm{Na}$, low in plant nutrients and toxic in $\mathrm{Cu}$. The $\mathrm{Cu}$, therefore, would have to be buried before successful revegetation could take place.

The Sacaton mine environment is poor, having sparse rainfall, shallow soils, and a hot-desert biome. These combined characteristics give rise to an extremely fragile ecosystem. In short, these adverse conditions of the spoils and refuse areas create difficulties in efforts to reclaim the disturbed areas. 


$$
\therefore \quad 44
$$

\section{THIS PAGE}

\section{WAS INTENTIONALLY}

\section{LEFT BLANK}




\section{1 HISTORY OF RECLAMATION}

The Sacaton mining plan calls for segregated stockpiling of the desert alluvium overburden. This material will be used to cover the rock dump faces and tailing dam slopes to allow revegetation along the slopes and the finished surface tops. Immediate implementation of this plan allows revegetation work to go on during mining operations rather than after they have ceased.

Efforts are being made to minimize the overall environmental impact of the Sacaton operation by including such considerations in all planning for accessing, stripping, mining, processing, and disposing of the waste rock and call for removing the industrial processing plant and covering the plant site and all disposal areas with the segregated desert alluvium. The entire area then will be revegetated. The effects of surface subsidence inherent with the block carving method will be minimized by depositing waste rock from the open-pit stripping operation over the subsidence zone to compensate for the reduced elevation before underground mining begins. This area will later be covered with alluvium and reseeded to facilitate surface reclamation.

Dust control, slope stability and aesthetics are three main reasons for the reclamation program at the Sacaton unit. Past efforts in mechanical dust control have generally failed, leaving the alternative of natural control through reclamation and revegetation as the most viable alternative.

Reclamation and revegetation at the Sacaton mine began as soon as construction and development allowed. And as mining progressed, the revegetation of the waste dump slopes has kept pace.

Revegetation was conducted chronologically as follows:

In 1973, when construction was nearly completed, a portion of the farm, which was retired from agricultural production for its water resources, was aerial-seeded to native grasses;

In 1974; the newly completed water tank hill was revegetated (Fig. 7.1) and the office area and front entrance areas were landscaped as well.

In 1975; the west face and a portion of the south face of the lower dump were revegetated.

In 1976; the completed tailing dam dike and the south face as well as a portion of the west face of the upper waste dump were reclaimed.

In addition, disturbed land within the plant area was also reclaimed. The mine unit itself is confined within the boundaries of approximately $6-1 / 2$ sections of land. Present mining disturbances encompass somewhat less than 3-1/2 sections of land, but current revegetation accomplishments have only reclaimed about 24 acres of slope surface. Revegetation of these disturbed surface areas cannot commence until all mining activity is terminated. In the interim, reclamation is correlated with mining operations by revegetation of the slope surfaces. 


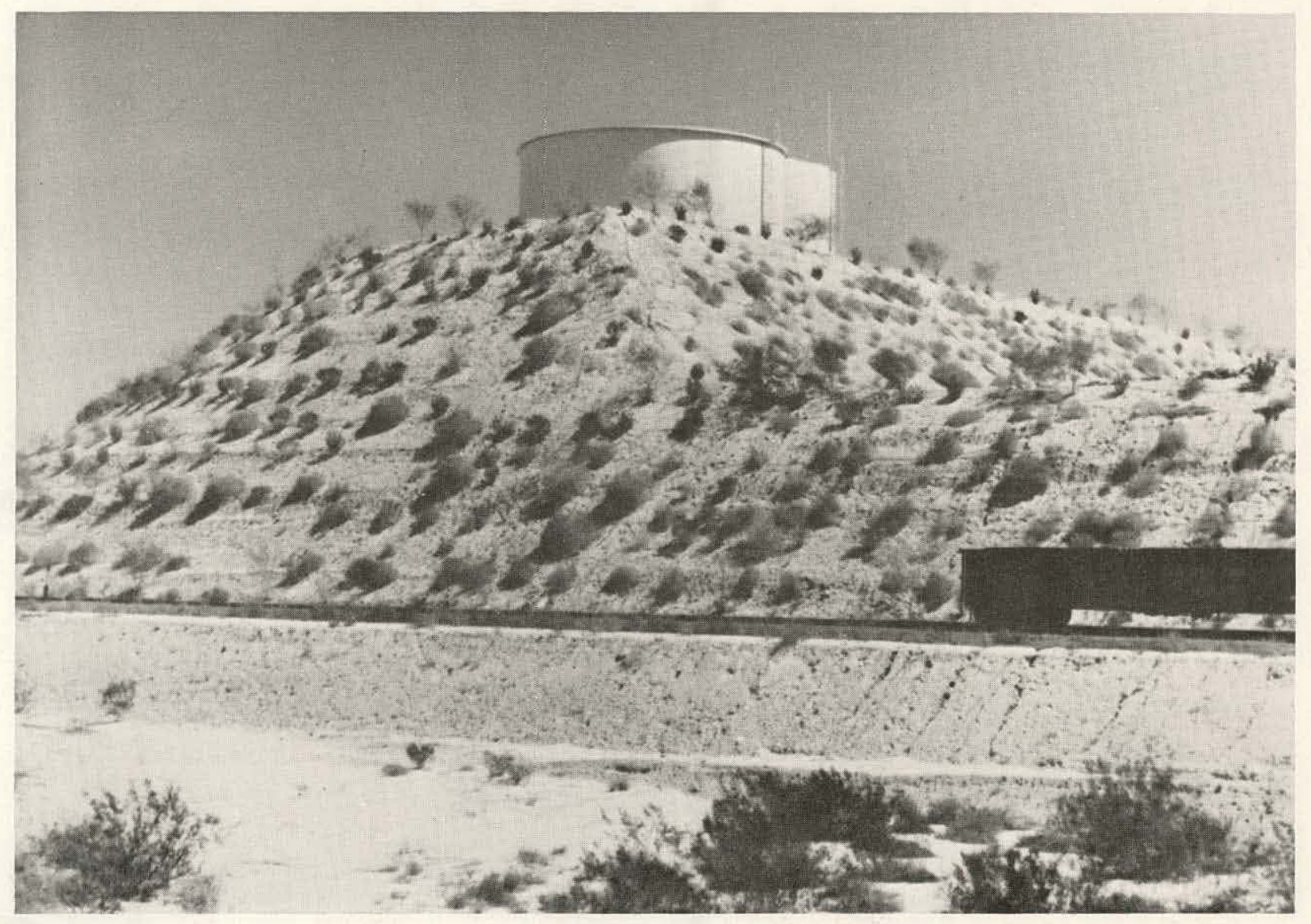

Fig. 7.1. Revegetated Water Tank Hill 


\subsection{CURRENT RECLAMATION PRACTICES}

The current reclamation program calls for the revegetation of the disturbed areas and waste material slopes. This procedure aids in both slope stabilization and aesthetics as well as in the long-term benefit derived from future land use values. Reclamation must begin with site stabilization, which first requires stable slopes. Because the Sacaton unit lies in a desert shrub environment (Fig. 7.2), and the natural rainfall will not support a grass vegetative community (especially on the very droughty slopes), the decision was made to revegetate with native shrubs and trees. The species used are selected on the basis of adaptability to the site conditions, growth and form for aesthetics, soil stabilizing characteristics, wildlife browse and cover values, forage values, and harmony with the adjacent desert flora

Since natural rainfall in this region is extremely variable and undependable, as well as very limited, irrigation is essential for initially establishing vegetation (Fig. 7.3). Once the vegetation has become established, irrigation can be slowly withdrawn to condition the plants to survive on the natural rainfall (Fig. 7.4). The drip system of irrigation was selected because of several advantages. It is especially adapted to shrub-tree plantings, promotes better and faster plant development, eliminates the hazards of erosion from more usual irrigation, conserves water, is adaptable to slopes, and is somewhat cheaper than sprinkler irrigation.

Before the disturbed areas are revegetated, each slope face of the dump and tailing pond is capped with alluvium or conglomerate material and finished to a 1.5:1 angle of repose. First, the water and filter system are installed and then the drip lines are installed on the slope surface. The slope is irrigated to presoak the slope and prepare it for planting. Nursery grown native trees and shrubs (Fig. 7.5) are hand planted next to each drip emitter on a $10 \times 15-f t$ spacing that totals approximately 335 plants/acre. A slow release fertilizer is supplied to each plant for growth and development over several months. Planting is done in the early spring to aid the plant in developing a substantial root structure before the beginning of the summer growing season. The initial irrigation schedule is monitored with soil tensiometers to maintain optimum soil moisture for best growth. Later, as the plants become established, irrigation is gradually discontinued. But, the amount of soil moisture to which the plants may be subjected is monitored to determine the actual amount of moisture stress.

The plant species used include several of the saltbushes (Atriplex canescens, polycarpa, torryii, lentiformis, hymenelytra, nymularia, shagodioiedes semibaccata, and mulleri), mormon tea (Ephedra sp.), mesquites (Prosopis $s p$. ), paloverdes (Cerciduim sp. and Parkinsonia aculeata), triangle-leaf bursage (Franseria deltoidea), desert broom (Baccharis sarothroides), creosote Larrea tridentata), Iycium (Lycuim sp.), senna (Cassia covesii), ruby sheepbush (Enchileana tomantosa), brittlebush (Encilia farinosa), hopseed bush (Dodonea viscosa), tree tobacco (Nicotiana glauca), sand hill grass (Bracharia ciliatissima) and globe mallow (Sphaeralcea sp.). Most of these species adapt well to the site conditions and after establishment prosper on the limited natural rainfall. The Mexican paloverdes (Parkinsonia aculeata) does particularly well on the low natural rainfall, and specimens of this species that have been without irrigation for 18 months demonstrate as good a growth form and vigor as similar plants still under irrigation. Some of the salt- 




Fig. 7.2 Desert Shrub Environment at Sacaton Mine 


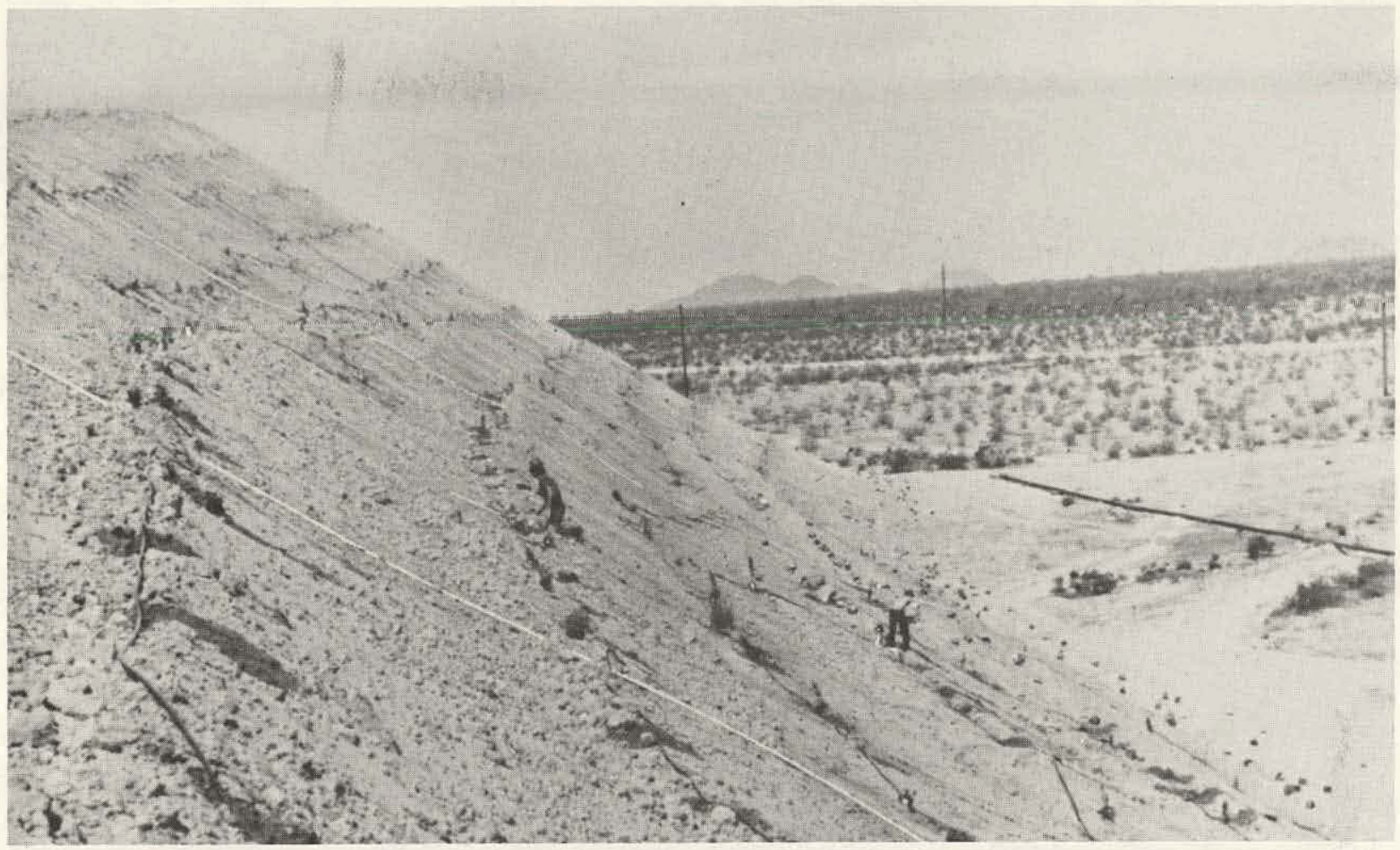

Fig. 7.3. Irrigation at Sacaton Mine

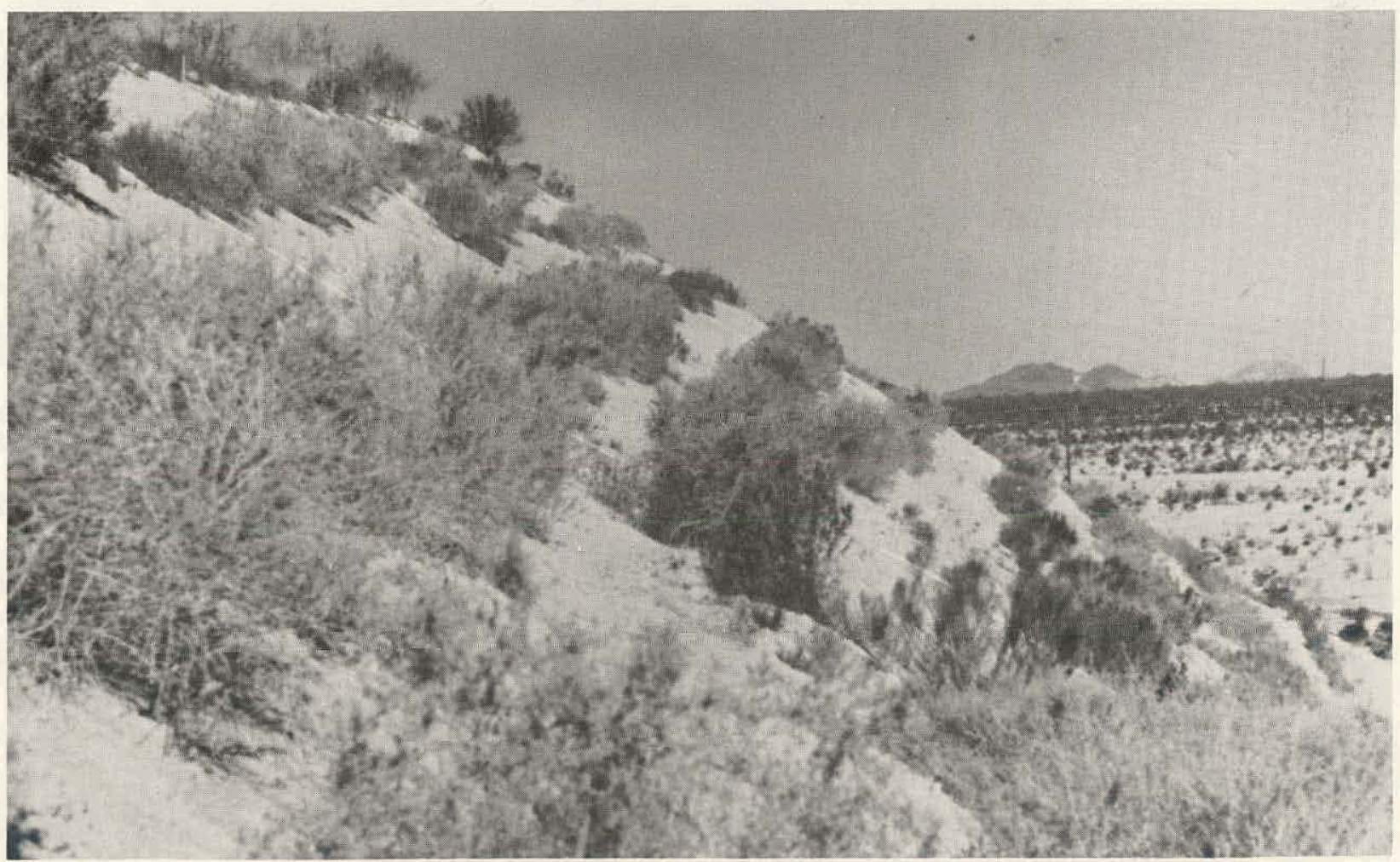

Fig. 7.4. Reclamation Site after Irrigation Withdrawal 


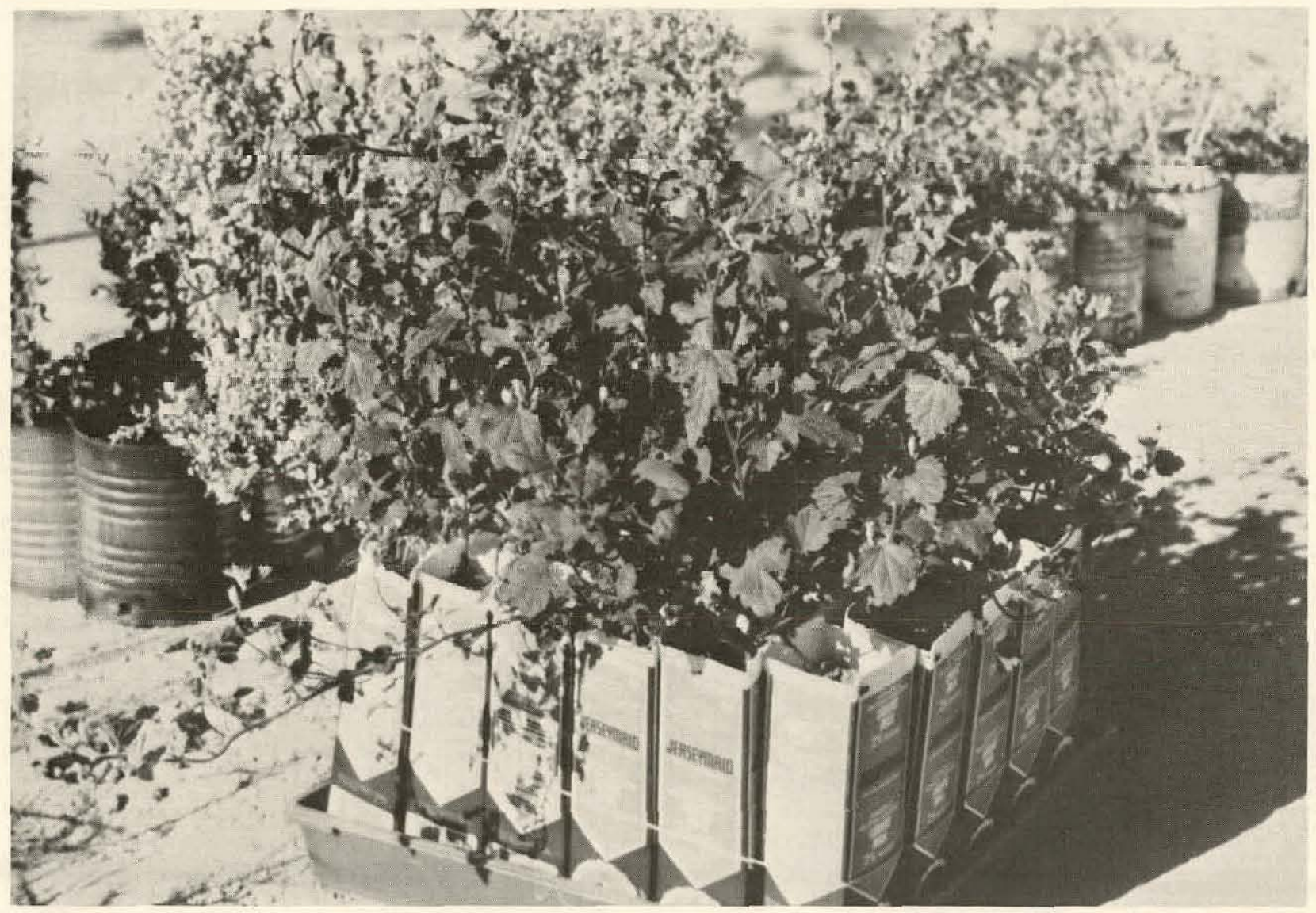

Fig. 7.5. Nursery-Grown Native Trees and Shrubs

bushes also do extremely well. Several species are reseeding themselves and beginning to fill in the bare areas between shrubs.

The concept behind the tree and shrub plantings is that they will provide stabilization from wind, water, and gravity erosion, and, at the same time, also provide a micro-environment favorable to the establishment of native annuals and plants blown or carried in from the desert. Presumably, the bare areas between the shrubs will fill in and provide a vegetative ground cover density that will approximate the natural vegetative density.

This revegetation program compares favorably with the general revegetation programs under way at other copper mining operations in southern Arizona. Techniques vary with each mine unit, since each site has its own unique characteristics that require specific techniques. A central problem of reclamation is maintenance of the vegetaiion once it is established. In most areas where rainfall is insufficient to support grass associations, sprinkler irrigation is generally used but not necessarily required in all of them. The trend is to revegetate with native or adapted species and put the land back into natural and productive conditions, as well as to stabilize the slopes and to improve the aesthetics. 


\subsection{AVAILABILITY OF SUPPLIES, LABOR, AND EQUIPMENT}

Among the major problems with mine revegetation are the availability of suitable plant materials and specialized equipment. Problems associated with nutrient deficiencies of spoil and waste materials can be ameliorated through soil amendments and soil modification techniques that are now available and being developed. The availability of seed and plant species that are best suited for the specific site requirements is often very limited. Many times inappropriate plant species have to be used simply because other species are unavailable. Also, the lack of available equipment to prepare the steep slopes of ponds and dumps for reclamation makes treatments such as pitting, discing, and harrowing impossible. A great deal more emphasis should be placed on developing and encouraging new markets to develop the equipment and supplies required to ensure a sound, well-managed, practical reclamation program.

\section{$7.4 \operatorname{COSTS}$}

In the consideration of a reclamation program, the economics involved have to be analyzed. Costs of revegetation vary with each specific mine site and each specific problem area. As techniques required vary, so do costs, which range from $\$ 300-\$ 5500$ per acre depending on site factors. At the Sacaton unit, hand planting gallon-sized native shrubs with drip irrigation costs as much as $\$ 1900$ per acre. Of this figure, approximately $\$ 1000$ per acre is spent for the irrigation system. Some of these costs are retrievable, as the irrigation system can be reused again on several areas to reduce the overall cost/acre. Labor and haulage of materials are also costly factors. Mine wages are high and present union contract agreements restrict revegetation work to union personnel, which increases the costs of the reclamation program.

\subsection{BENEEITS}

Because there are no plans at this time for near-term production of salable crops on the reclaimed areas, quantification of identifiable benefits directly attributable to the reclamation program is not possible utilizing existing data. Many of the benefits will actually accrue after mining has ceased, in about thirty or more years, and hence these long-term benefits cannot be quantified at this time. In the short-term, the greatest benefits will probably derive from aesthetics, slope stabilization, and pollution control, with some direct benefit to ASARCO in the form of local acceptance and public image. When portions of the site are opened to grazing, it is likely that improved management practices will result in a better grazing environment than existed prior to mining, when much of the area was being drastically overgrazed. The future use of the site for residential, industrial, commercial, or other intensive development will depend not only on the engineering aspects of the reclamation program but also on the future local and regional demand for such developments. The site is being constructed in such a way that if local demand for housing or industrial sites should develop, the reclaimed area can be used to help satisfy that demand. 


\subsection{RECLAMATION LAWS}

Although mine reclamation work and research has been conducted by the mining companies individually since about 1918, it has been only recently that any land use legislation has been passed, but there are no mine reclamation laws in the State of Arizona. Most of the mining companies are conducting reclamation programs to protect the future surface resources they own and to respond to public pressures for improved aesthetics and reduced environmental damage. The only land use regulations regarding reclamation are those that may pertain to the issuance of permits or land leases for mining and waste disposal. The State Land Department requires that waste disposal berms be no higher than $50 \mathrm{ft}$ in elevational lift and each successive lift must be offset $200 \mathrm{ft}$ from the edge of the lower level. The Bureau of Indian Affairs requires that the mining plan include a comprehensive reclamation plan prior to issuance of a permit on Indian reservation 1 and.

\subsection{RECLAMATION PLANNING}

Reclamation planning is generally an individual function of each mine and mining company. ASARCO has an agronomist who coordinates and develops a reclamation program for each of the mine units. Each of the units is then responsible for the actual work and provides the necessary labor. At the Sacaton unit, for example, one man has the responsibility for the maintenance and operation of the irrigation system and to ensure that the plants are irrigated on schedule. This work is closely supervised by the agronomist and any additional labor needed for project work or large repair maintenance requirements is drawn from the general labor pool.

The reclaimed lands at the Sacaton mine are excluded from the heavy grazing pressures that prevailed prior to mining. Future land use may include grazing after the mine is terminated. The 1 and will be used for the highest resource use attainable. The reclamation planning costs for this program are extremely difficult to ascertain, as they are a part of the total reclamation costs and are not itemized separately by ASARCO.

\subsection{RECLAMATION RESEARCH PROGRAM ONSITE}

Reclamation research to develop new and better techniques, to find new plant material, and to discover ways to reduce reclamation costs constitutes a continuing program at ASARCO. Each unit has individual and separate programs as well as coordinated programs. Some of this research is aided by the University of Arizona, Cooperative Extension Service, Soil Conservation Service, SCS Plant Materials Center, and private industrial suppliers developing new products. The ASARCO agronomist is principally responsible for the development and results of these tests. Most of the research is done as part of the total reclamation cost. At the Sacaton unit, a test on the farm area is being conducted with the University of Arizona to determine whether a form of native gourd can be profitably produced on these abandoned farm lands without irrigation. To date, no significant data on this program is available, as it takes several years for these gourds to become established and to produce crops. 
Future plans call for the possible testing of other native plants for agricultural production or development of a native seed plantation on these lands. In conjunction with the Plant Materials Center, new species and planting techniques are also being tested to improve the total reclamation program.

Tests on the farm, which were done in cooperation with the local SCS office, showed that native species are not conducive to aerial seeding techniques. To find ways of reducing revegetation costs, several new drip systems are being tested. Several of the manufacturers have donated equipment for testing under very adverse conditions. Since all of the drip systems available were developed for agricultural application, many are not adaptable to mine reclamation situations. Tests with paper erosion control fabric are showing some potential for seed germination and plant establishment without irrigation. The fabric seems to hold moisture and when used as a ground cover can provide a miniature greenhouse environment (Fig. 7.6). To further reduce costs, a technique of hydroseeding native shrub species is being tested with different drip irrigation systems. It appears to be working satisfactorily and is much cheaper than hand planting. It also produces a more natural appearance. Another cost reduction technique being tested is the use of tubling seedlings. The plants are grown in containers that promote long, deep tap root development. They cost much less than the gallonsized plants presently used, are easier to plant, and have a better root



Fig. 7.6. Use of Paper Erosion Control Fabric 
structure. The preliminary tests indicate high survival and rapid growth rates. Growth has proven to be almost as rapid as that of gallon-sized stock. Tests have been initiated with a chemical humictant applied to the soil surface to reduce evaporative losses, reduce water consumption, and improve plant development. Results are not yet available. All the tests that show merit are developed and incorporated into the revegetation plans to improve the reclamation program.

\subsection{DATA INVENTORY}

Baseline environmental data are maintained at the Sacaton site. In addition to a standard weather station, vegetative transects are also made periodically. The transects provide data on plant density, composition, and ecological succession for use in comparing reclamation work with the natural areas surrounding vegetational cover density of $23-26 \%$ on reclamation sites as compared to an average of $18 \%$ cover on the natural surroundings. Soil moisture is monitored on the reclamation sites to determine if the plants are stressed, especially during the irrigation period and also as irrigation is being withdrawn.

\subsection{UNIQUE PROBLEMS}

There are several reclamation problems that are unique to the copper mining industry. Probably foremost is the aridity of the southwestern climate where a majority of the mines are located. Coupled with this aspect are the unusually high temperatures and naturally alkaline soils. Topsoil for waste material amendment or burying spoils is not available in the area, and suitable soil material is also lacking if not totally absent. And water is, of course, scarce in most cases.

The mill tailing wastes also have unique properties. They are extremely erosive, devoid of organic matter, deficient in nutrients and often have extreme $\mathrm{pH}$ problems (either too acidic or too alkaline). They also have high salt contents and often contain toxic levels of copper and other metallic copper mines in the area. In addition, the shortage of native plant seeds and seedlings seriously restricts the reclamation alternatives for any site in the arid southwest. 


\section{OBSERVATIONS FOR PLANNERS}

This case study illustrates in part that revegetation of much of a copper mine site in the southwest is feasible under existing technological and economic conditions. Reclamation planning and plan implementation are, however, done at the discretion of the mining company. Arizona is a state that has no reclamation laws. Mining in Arizona also has a statutory exemption, which dates back to 1939, from local planning devices such as zoning. In addition, the copper mining industry is one in which traditionally only about $7 \%$ of the area affected each year is reclaimed. It is therefore an area of great concern to planners. But there is a need for an incentive to effectuate more reclamation planning and implementation. This incentive might come in the form of effective local land use planning that takes into account the opportunities for creating new landscapes in mined areas to satisfy local or regional land use needs.

A cooperative effort between the copper industry and local or regional planning agencies would help ensure that opportunities for reclaiming land to a productive use, and thus enhancing its value to both the industry and the public, will not be missed. Land use analyses and marketing strategies can be tools for the reclamation planner to design uses for mined land that will enable the company to recover part of its investment in the purchase price of the land.

Because of the adverse physical conditions, the nature of the mining and processing operations, the relatively low land values, and the lack of reasonable reclamation laws, integrated reclamation and land use planning might be more difficult to implement in the copper mining industry of the southwest than in any of the other study sites addressed by this program. Low population pressure near a mining site can be a factor responsible for low land use demand, which affects land values. Each site needs to be evaluated on an individual basis to take advantage of whatever potential value its specific location might afford. Revegetating the outslopes of berms might improve aesthetics, but does little to assure the eventual reuse of the mined area.

An analysis of local housing, recreation, comercial, industrial, and other site needs should be conducted to determine what the use potential for mined areas might be in 25 to 30 years when some of these mines are to be abandoned. Long-term planning, such as that necessary for a mine with a life span of several decades, can benefit greatly from public sector planning input into the industry's reclamation plans. 
THIS PAGE

WAS INTENTIONALLY

LEFT BLANK 
APPFNDIX: OFFICES, MINING PROPERTIES, AND ASSOCIATES OF ASARCO, INC.

WORLD WIDE OPERATIONS

The offices, divisions, mining properties and associates of ARARCO are summarized below:

MAIN OFFICE - ASARCO

New York, New York

MAIN OFFICES - ASSOCIATED COMPANIES

Brisbane, Australia

Lima, Peru

Mexico, D.F., Mexico

ADMINISTRATIVE OFFICES

Knoxville, Tennessee

Salt Lake City, Utah

Tucson, Arizona

Wallace, Idaho

CENTRAL RESEARCH LABORATORIES

South Plainfịeld, New Jersey

SMELTERS. AND REFINERIES

Copper

Amaril1o, Texas (Refinery)

El Paso, Texas (Smelter)

Hayden, Arizona (Smelter)

Zinc

Columbus, Ohio (Zinc Oxide)

Corpus Christi, Texas (Electrolytic Plant)

East Helena, Montana (Slag Fuming Plant)

E1 Paso, Texas (Slag Fuming Plant)

Hillsboro, Illinois (Zinc Oxide)

Lead

East Helena, Montana (Smelter)

E1 Paso, Texas (Smelter)

Glover, Missouri (Smelter, Refinery)

Omaha, Nebraska (Refinery)

Cadmium, High-Purity Metals

Denver, Colorado (Refinery 
OPERATING MINING PROPERTIES

Buchans (Zinc, Lead, Copper, Silvër)

Buchans, Newfoundland, Canada

Coeur (Silver, Copper)

Wallace, Idaho

Grandux (Copper)

Stewart, British Columbia, Canada

Ground Hog (Zinc, Lead, Silver)

Vanadium, New Mexico

Manchester (Ilmenite)

Manchester Township, New Jersey

Lake Asbestos of Quebec, Ltd. (Asbestos)

Black Lake, Quebec, Canada

Leadville (Zinc, Lead, Silver)

Leadville, Colorado

Midland Coal Company (Coal)

Allendale, Wyoming, Illinois

Edwards, Edwards, Illinois

Elm, Trivoli, Illinois

Mecco, Victoria, Illinois

Mission (Copper, Silver, Molybdenum, Zinc)

Sahuarita, Arizona

Northern Peru Mining Corporation

Quiruvilca (Copper, Zinc, Lead, Silver)

Quíruvilca, Peru

Sacaton (Copper) Casa Grande, Arizona

San Xavier (Copper) Sahuarita, Arizona

Silver Bell (Copper, Molybdenum, Silver)

Silver Bell, Arizona

Tennessee Mines Division

American Limestone (Sand, Gravel, Limestone) Knoxville, Tenn.

Coy (Zinc) Jefferson County, Tknnessee

Imme1 (Zinc) Knox County, Tennessee

Mascot (Zinc) Mascot, Tennessee

New Market (Zinc) Jefferson County, Tennessee

Young (Zinc) Jefferson County, Tennessee 
FEDERATED METALS DIVISION

(Acoustilead, additives and hardeners, aluminum alloys, babbitt, brazing alloys, bronze, cathodic protection products, continuous cast bronze road and tube, fusible alloys, jewel metal, lead products, nickel salts, plating anodes, solder, type metal, zinc dust, zinc oxide)

Houston, Texas

Newark, New Jersey

Perth Amboy, New Jersey

San Francisco, California

Sand Springs, Oklahoma

Somerville, New Jersey

Trenton, New Jersey

Whiting, Indiana

ASARCO Federal Products Division

Somerville, N. J. (Bronze bearings, bushings and parts)

Lone Star Lead Construction Corp.

Houston, Texas (Lead burning)

Federated Genco, Ltd.

(Solder, type metal, babbitt, lead products, lead construction) Burlington, Ontario, Canada

Montreal, Quebec, Canada

Toronto, Ontario, Canada

METAL FINISHING PLANTS

Enthone, Inc.

Chicago, Illinois (Metal finishing chemicals)

Cleveland, Ohio (Plating chemicals)

Toronto, Canada (Metal finishing chemicals)

West Haven, Connecticut (Metal finishing chemicals)

Ionic International Inc.

Warren, Michigan (Automatic plating equipment)

\section{ASSOCIATED MINING COMPANIES}

Industrial Mineral (Zinc, Lead, Silver, Gold, Copper, Coal,

Coke, Fluorspar)

Mexico, D.F., Mexico

M.I.M. Holdings Ltd.

Mount Isa (Copper, Lead, Silver, Zinc)

Queensland, Australia

Hilton (Lead, Silver, Zinc)

Queens land, Australia 


\section{ASSOCIATED MINING COMPANIES (Cont'd)}

Bowen Consolidated Coal Mines (Coal

Bowen, Queensland, Australia

Britannia Lead Company Ltd (Lead Refinery)

Northfleet, Kent, England

Copper Refineries Pty, Ltd.

Townsville, Queensland, Australia

Neptune Mining Company (Zinc, Lead, Gold Silver)

Bonanza, NIcaragua

Southern Peru Copper Corporation (Copper, Molybdenum)

Cuajone, Peru

Toquepala, Peru 


\section{BIBLIOGRAPHY}

Bengson, S.A., Drip Irrigation for Revegetating Steep Slopes in an Arid Environment, Progressive Agriculture in Arizona XXVII.1 (n.d.).

Bengson, S.A., How Drip Irrigation Revegetates Mine Wastes in an Arid Environment, Mining Engineering, 28(8):45-46 (1976).

Bengson, S.A., Drip Irrigation to Revegetate Mine Wastes in an Arid Environment, J. Range Management; 30(2):143-147 (1977).

Burgin, L. B., Time Required in Developing Selected Arizona Copper Mines, U.S. Department of the Interior Information Circular 8702 (1976).

Day, A.D., and K.L. Ludeke, Stabilizing Copper Mine Tailing Disposal Berms with Giant Burmudagrass, J. Environ. Quality, 2(2):314-315 (1973).

Day, A.D., and K.L. Ludeke, E. Amougo and T.C. Tucker, Copper Mine Wastes: Good Potential as Medium for Growing Livestock Forage, Engineering Mining J., $177(2): 90-92$ (1976).

Dean, K.C., R. Havens, and K.T. Harper, Chemical and Vegetative Stabilization of a Nevada Copper Porphyry Mill Tailing, U.S. Bureau of Mines, Report of Investigations 7261 (1969).

DeReemer, E.D., and D.A. Bach, Current Activities in Mine Tailings Stabilization and Beautification, unpublished report from Agronomics, Inc., Avondale, Arizona (1974).

Ludeke, K.L., Soil Properties of Materials in Copper Mine Tailing Dikes, Mining Congress J., 59(8):30-36 (1973).

Ludeke, K.L., Vegetative Stabizization of Tailings Disposal Berms, Mining Congress J., 59(1):32-39 (1973).

Ludeke, K.L., Vegetative Stabilization of Copper Mine Tailing Disposal Berms of Pima Mining Company, Miller-Freeman Publications, Inc., International Standard Book Number 0-87930-020-5, World Mining Book, pp. 377-411 (1973).

Nowotny, A., and W. Wood, Revegetating Mine Spoils in a Desert Shrubland, Soil Conservation, U.S. Dept. of Agriculture, Soil Conservation Service Bulletin (1975).

University of Arizona Cooperative Extension, Guide to Improvement of Arizona Rangeland, Service Bulletin A-58 (1973). 